\title{
Lao People's Democratic Republic: Selected Issues and Statistical Appendix
}

This Selected Issues paper and Statistical Appendix for Lao People's Democratic Republic was prepared by a staff team of the International Monetary Fund as background documentation for the periodic consultation with the member country. It is based on the information available at the time it was completed on February 27, 2006. The views expressed in this document are those of the staff team and do not necessarily reflect the views of the government of Lao People's Democratic Republic or the Executive Board of the IMF.

The policy of publication of staff reports and other documents by the IMF allows for the deletion of market-sensitive information.

To assist the IMF in evaluating the publication policy, reader comments are invited and may be sent by e-mail to publicationpolicy@imf.org.

Copies of this report are available to the public from

International Monetary Fund • Publication Services

700 19th Street, N.W. • Washington, D.C. 20431

Telephone: (202) 6237430 • Telefax: (202) 6237201

E-mail: publications@imf.org• Internet: http://www.imf.org

Price: $\$ 18.00$ a copy

\section{International Monetary Fund Washington, D.C.}





\section{INTERNATIONAL MONETARY FUND}

\section{LAO PEOPLE'S DEMOCRATIC REPUBLIC}

\section{Selected Issues and Statistical Appendix}

Prepared by Shinichi Nakabayashi, Kotaro Ishi, Murtaza Syed (all APD), Tokhir Mirzoev (PDR), and Prachi Mishra (FAD)

Approved by the Asia and Pacific Department

February 27, 2006

Contents

I. Reforming Center-Province Fiscal Relations in Lao P.D.R. 3

A. Introduction.................................................................................... 3

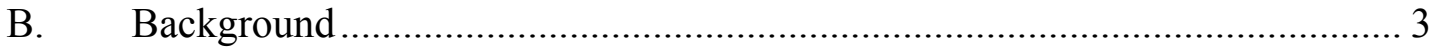

Chart 1. General Government Fiscal Trends (1995-2005)........................... 5

Chart 2. Structure of Center and Province Fiscal Arrangements, 2002/03 ...... 6

C. Center-Province Relations in Lao P.D.R. ……………………………...... 8

Box 1. Recent History of Decentralization in Lao P.D.R............................. 9

D. Regional Experience: China and Vietnam.................................................... 12

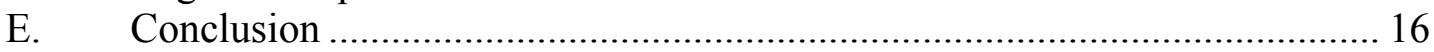

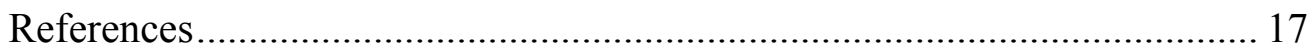

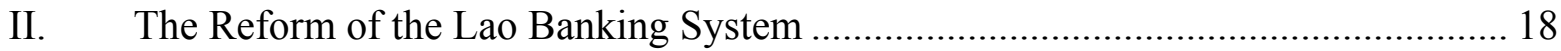

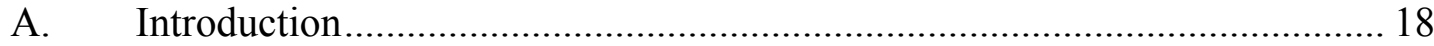

B. The Lao Banking System...................................................................... 18

C. Bank Restructuring Program................................................................. 20

D. Assessment of Progress........................................................................... 21

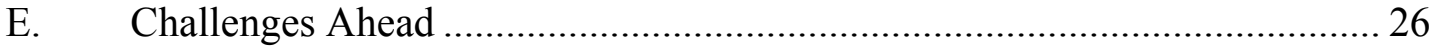

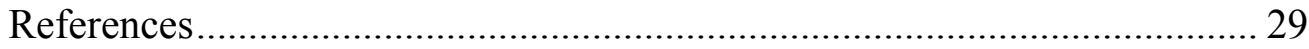

Statistical Appendix Tables

1. Real GDP by Industrial Origin, 2000-2004 ……................................................... 30

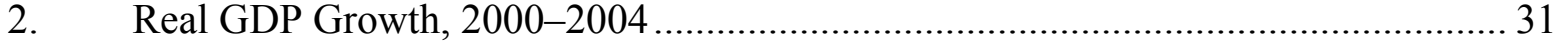

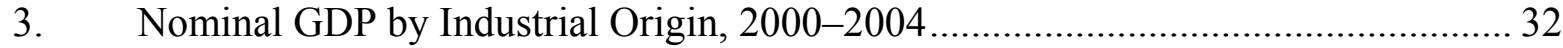

4. Output of Major Commodities, 2000-2004 ……….................................................... 33

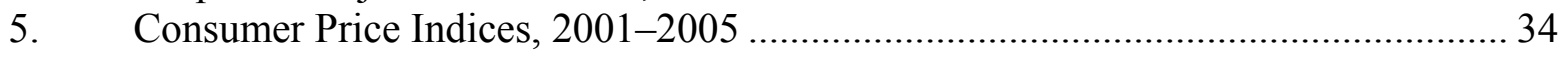

6. Consumer Price Indices Components, 2003-2005 …………………………............ 35

7. General Government Operations, 2000/01-2004/05 .................................................. 36

8. General Government Revenue, 2000/01-2004/05 .............................................. 37

9. General Government Expenditures, 2000/01-2004/05 .......................................... 38 


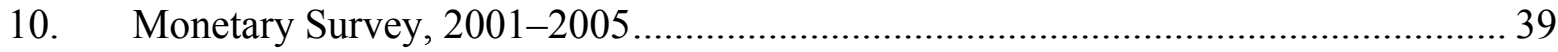

11. Balance Sheet of the Bank of the Lao P.D.R., 2001-2005 .................................. 40

12. Summary Balance Sheet of All Commercial Banks, 2001-2005 ........................... 41

13. Summary Balance Sheet of State-owned Commercial Banks, 2001-2005 .............. 42

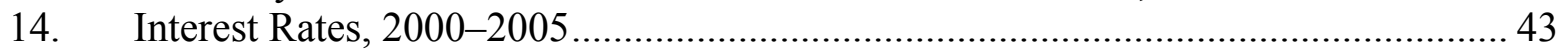

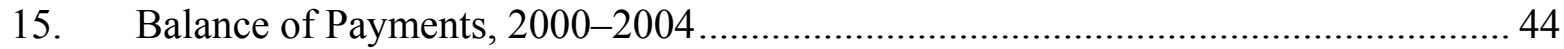

16. Merchandise Trade by Major Commodity, 2000-2004 …................................... 45

17. External Aid and Loan Disbursements, 2000-2004 .............................................. 46

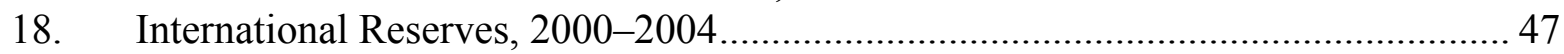

19. Debt Stock and Debt Service, 2000-2004 …....................................................... 48

20. Composition of Net Foreign Income, 2000-2004 ............................................. 49

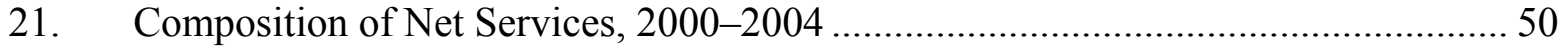

22. Domestic and Foreign Investment by Sector, 1999-2003 ..................................... 51

23. Domestic and Foreign Investment by Country, 1999-2003 ................................ 52 


\section{Reforming Center-Province Fiscal Relations in Lao P.D.R. ${ }^{1}$}

\section{A. Introduction}

1. This chapter presents a preliminary analysis of the role of center-province relations in the fiscal reform agenda in Lao P.D.R. The lack of central control over revenue and treasury operations in the provinces has long been seen as a key impediment to raising national revenues and improving fiscal management in Lao P.D.R. However, there has been greater recognition in recent years that reform of center-province fiscal relations is central to making progress in these areas. This reflects the fact that powerful provinces are unlikely to cede control over revenue and treasury functions until a credible revenue-sharing mechanism is in place.

\section{The chapter also explores what lessons Lao P.D.R. might learn from its} neighbors in the region. The chapter focuses in particular on reforms in China and Vietnam, who launched reforms in the last decade to overcome similar challenges in center-province relations as those faced by Lao P.D.R. The chapter concludes that the key element of the reforms in these two countries was that agreement was reached on a revenue-sharing mechanism that enabled the administration of major taxes to be transferred to the center. This greatly improved the efficiency of tax administration, resulting in a significantly increased revenue effort. However, achieving consensus on an appropriate revenue-sharing mechanism is not straightforward, as it involves striking a delicate political balance between equity considerations and the need to elicit support from richer, more powerful provinces.

3. The paper is organized as follows: Section B presents the background to the current debate on center-province relations, Section $C$ discusses the existing fiscal arrangements in Lao P.D.R, and Section D examines the main features of the inter-governmental fiscal systems in China and Vietnam. Section E concludes.

\section{B. Background}

4. Raising the revenue effort has been a longstanding objective in Lao P.D.R. At around 11 percent of GDP, Lao P.D.R. has one of the lowest revenue efforts among low income countries (Figure 1), severely constraining the government's ability to meet the country's pressing development needs. ${ }^{2}$ Despite sustained attempts, little progress has been made over the last decade in raising the revenue effort (Chart 1). Performance was particularly disappointing under the last PRGF program (2001-2005), when instead of rising, revenues fell by over 2 percentage points of GDP. While the government contained the cash

\footnotetext{
${ }^{1}$ Prepared by Ms. Prachi Mishra (ext. 39409).

${ }^{2}$ Lao P.D.R. is one of the least developed countries in South-East Asia. It is ranked 133 out of 175 countries according to the UN Human Development Index.
} 
budget deficit, the lack of progress in revenue mobilization resulted in a significant squeeze on spending.

Figure 1. Revenues in Selected Low Income Countries, 2002/03

(In percent of GDP)

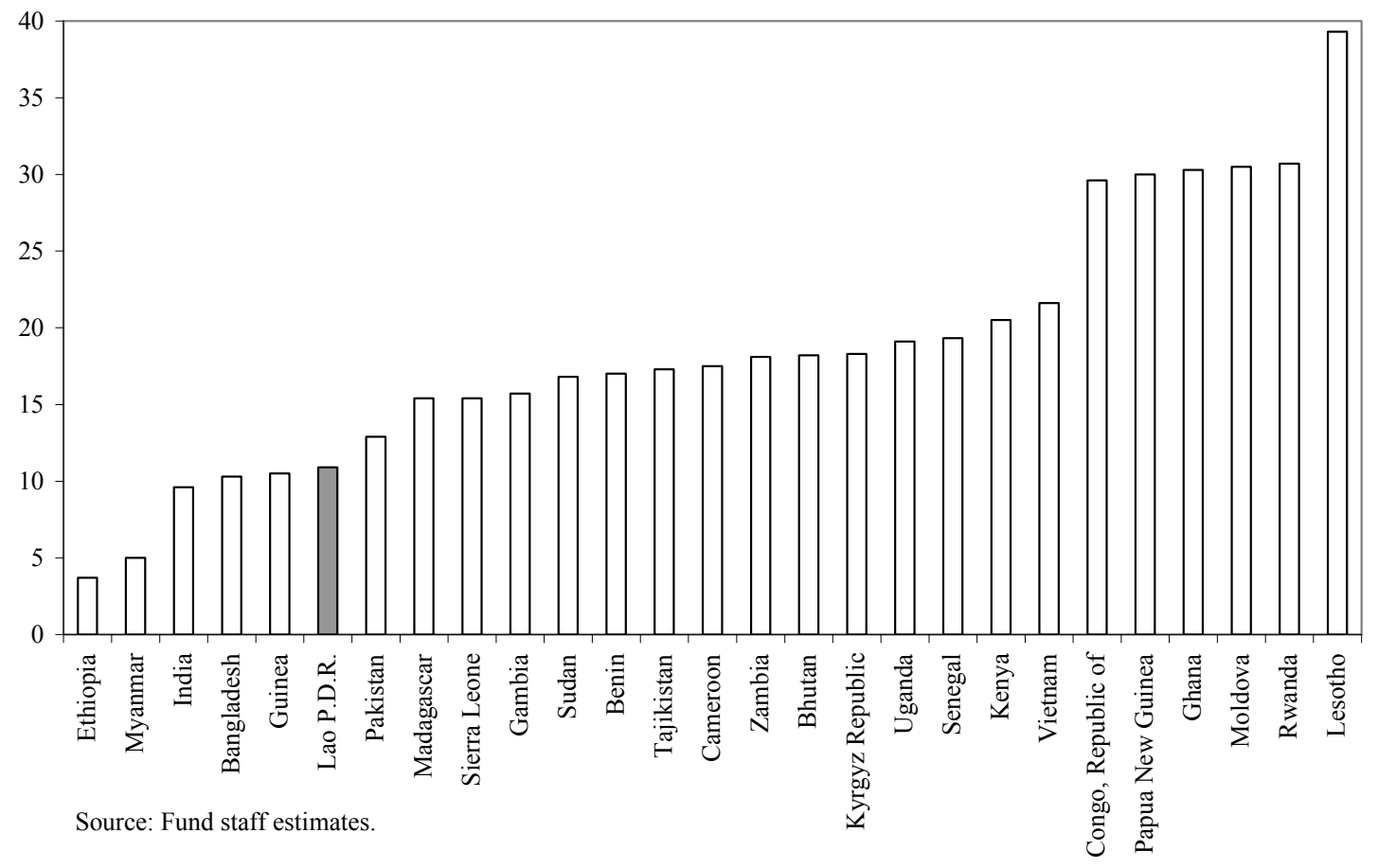

5. While a number of factors have contributed to the disappointing progress in revenue mobilization, a fragmented revenue administration is seen as the key factor. The sharp decline in revenues since 2001 partly reflects lower resource revenues (timber royalties), following the government's decision to impose a ban on the export of unprocessed $\operatorname{logs}$ in 2002. A rationalization of the finances of the state-owned commercial banks and state-owned enterprises has also reduced income taxes and dividends from the state sector. Weak technical capacity has also played a role. However, a decentralized revenue administration, in which provinces have responsibility for collecting major taxes, is widely seen as the most important contributory factor. ${ }^{3}$

6. Currently, the bulk of revenues are collected at the provincial level (Chart 2). About two-thirds of total revenues are collected by provinces. All import duties, natural

\footnotetext{
${ }^{3}$ In Lao P.D.R., this is commonly referred to as an absence of "vertical control" over revenue administration.
} 


\section{Chart 1. General Government Fiscal Trends (1995-2005)}

(In percent of GDP)

Domestic Revenues

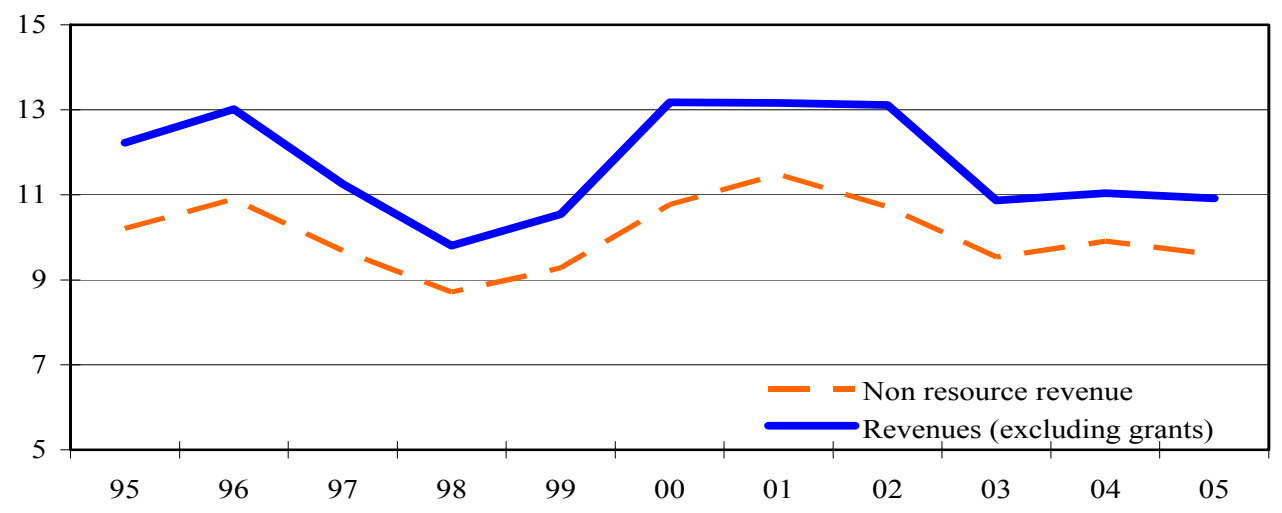

Expenditures

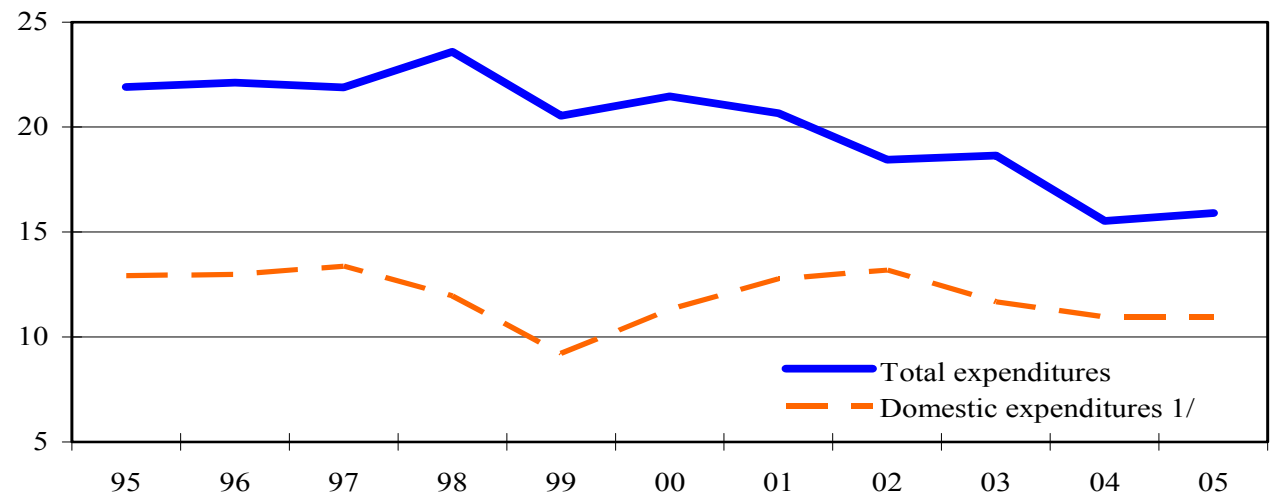

1/ Excludes donor-financed capital expenditures.

Government Balance

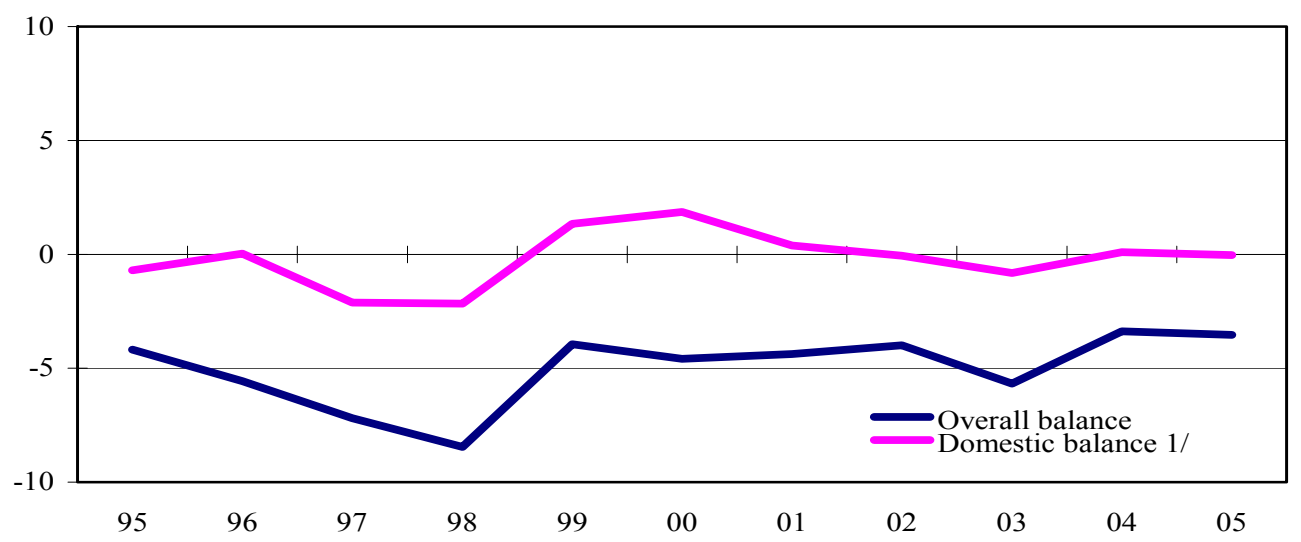

1/ Domestic revenues minus domestic expenditures.

Source: Fund staff estimates. 


\section{Chart 2. Structure of Center and Province Fiscal Arrangements, 2002/03} (In percent of GDP)

Revenues

(In percent of GDP)

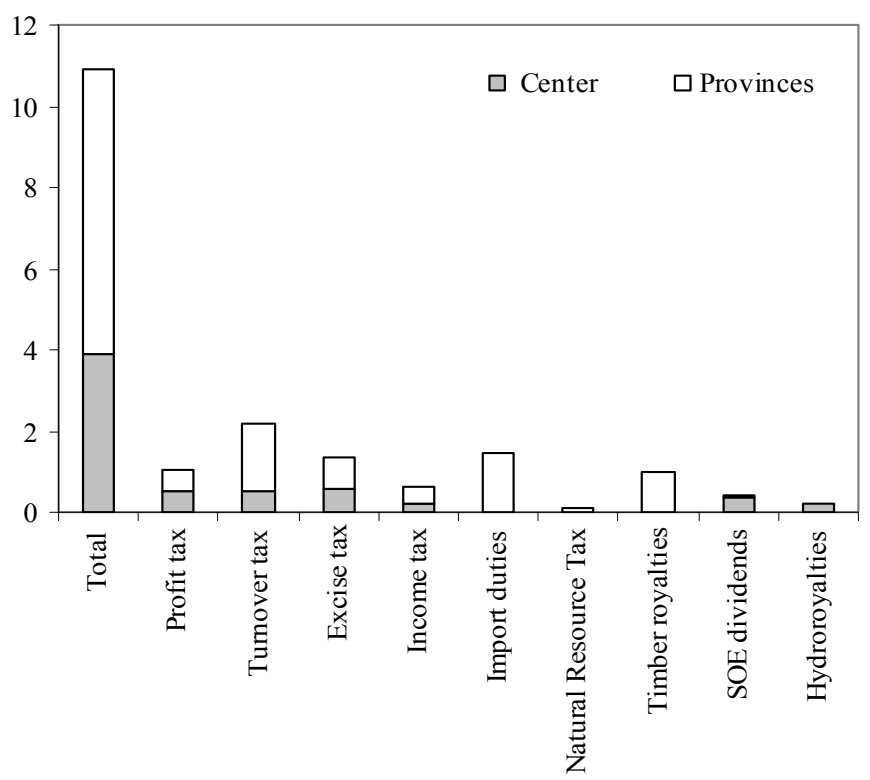

Expenditures by Sector

(In percent of GDP)

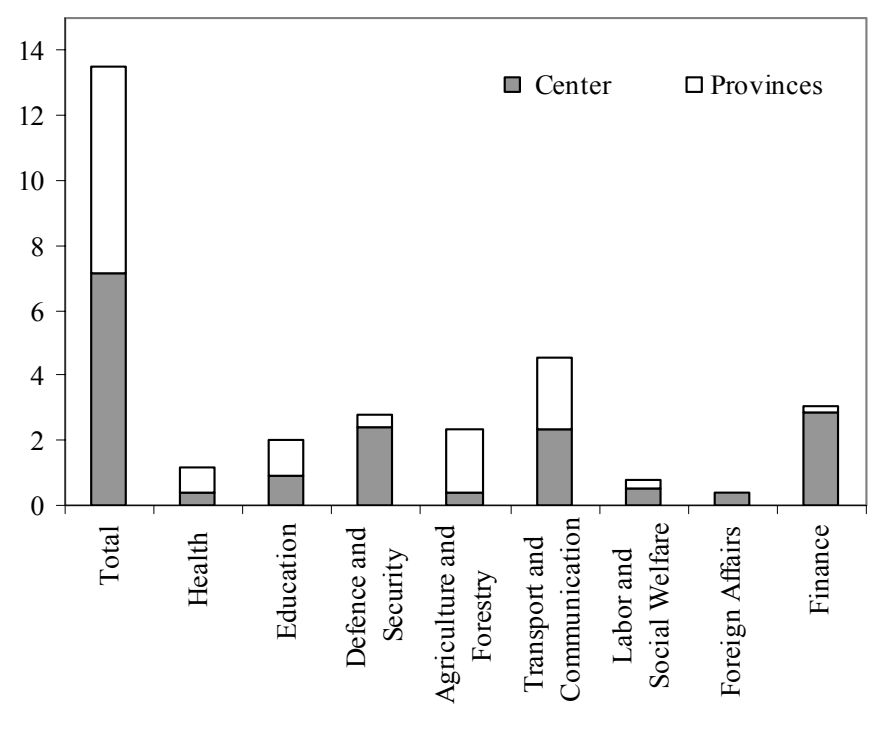

Targeted and Actual Surpluses 1/

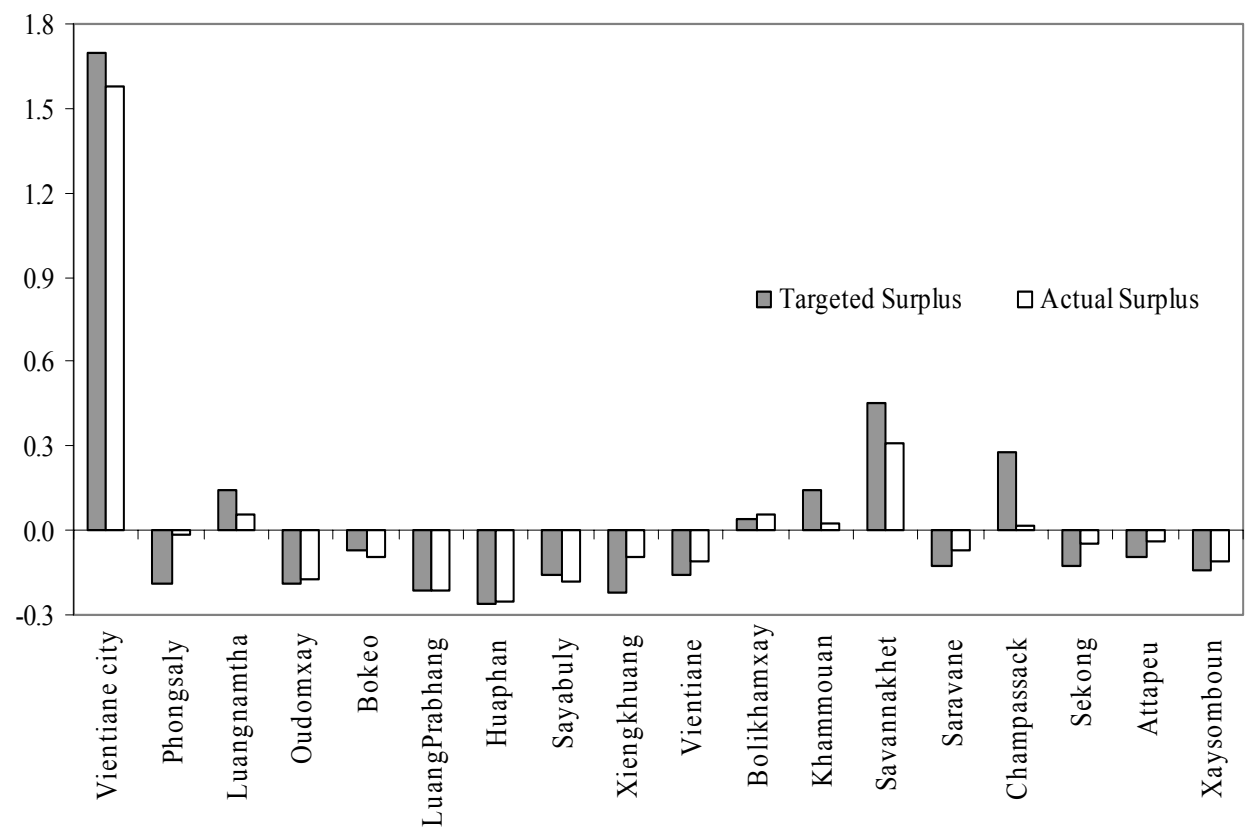

1/ Revenues minus domestic expenditures. 
resource taxes, timber royalties and more than half of profit and income taxes, turnover and excises are collected by the provinces. Apart from SOE dividends and hydro-royalties, the only revenues collected by the center are from the 100 largest taxpayers administered by the central large taxpayer's unit (LTU).

\section{While the share of expenditure undertaken by the provinces is also high, the} center is dependent on transfers from a small number of rich provinces. ${ }^{4}$ Most provinces are "deficit" provinces, in the sense that they are dependent on transfers from the center to meet their spending needs (provinces are not permitted to borrow). There are only 6 "surplus" provinces, of which Vientiane City, Champassack, and Savannakhet are the most important. ${ }^{5}$ These provinces provide transfers to the center to help finance expenditures in the center as well as the deficit provinces. While the latest data on the outturn of provincial revenues and expenditures is for $2002 / 03$, the basic structure of the budget has remained broadly unchanged. In 2002/03:

Structure of Central Government's Domestic Budget

(In percent of GDP)

\begin{tabular}{lrr}
\hline 2002/03 & Target & Outturn \\
\hline Revenues & 6.0 & 4.6 \\
Expenditures 1/ & -8.5 & -7.1 \\
Central Government Balance & -2.5 & -2.5 \\
& & \\
Transfers to Deficit Provinces & -1.9 & -1.4 \\
& & \\
Financing & & 2.0 \\
Transfers from surplus provinces & 2.8 & 1.9 \\
Financing from other sources & 1.6 & \\
\hline
\end{tabular}

Source: Lao P.D.R. Budget Book FY 03/04.

1/ Includes amortization and excludes transfers to deficit provinces.

- The central government's own revenue collections amounted to $4 \frac{1}{2}$ percent of GDP.

- Its spending needs, including transfers to deficit provinces, amounted to $81 / 2$ percent of GDP.

- The surplus provinces made transfers of 2 percent of GDP, with the remainder financed through borrowing from donor budget support and the banking system.

8. In general, the transfers from the surplus provinces are less than targeted in the budget plan. ${ }^{6}$ Of the six provinces that were targeted to have surpluses in $2002 / 03$, the

\footnotetext{
${ }^{4}$ About half of domestic expenditures (i.e., excluding donor-financed capital expenditure) are administered by the provinces.

${ }^{5}$ Lao P.D.R. is divided into 18 provinces, including one prefecture (the capital Vientiane) and one special zone.

${ }^{6}$ Paragraph 10 provides a more detailed discussion of the system of targets and transfers.
} 
surplus of only one, the relatively small province of Bolikhamxay, exceeded its budget target. The transfers from the remainder all fell short of their target, mainly reflecting shortfalls in revenue collections. The aggregate shortfall can be significant ( 0.8 percent of GDP in 2002/03) and is borne largely by the deficit provinces in the form of reduced transfers from the center. The current system, therefore, is not only inefficient in terms of mobilizing aggregate resources, it also adversely impacts the equity of the distribution of public resources across provinces.

\section{Reforming the current fiscal system is difficult because provinces have} historically been very powerful in Lao P.D.R. (Box 1). Provincial governors have strong support from regional factions within the party hierarchy and are also individually powerful, often outranking cabinet ministers. Central control over fiscal affairs in the provinces has therefore tended to be weak. The power of the provinces also explains why efforts to centralize fiscal management may not succeed in the absence of broader reforms to center-province relations. Rich provinces are unlikely to cede control over key functions such as revenue administration unless credible revenue-sharing mechanisms are put in place. However, international experience suggests that an efficient fiscal management system based on a decentralized structure can be put in place, and that the returns from such a reform can be high.

\section{Center-Province Relations in Lao P.D.R.}

10. In principle, Lao P.D.R. operates a deconcentrated fiscal system, but in practice fiscal management is highly decentralized. ${ }^{7}$ According to the law, all revenues are national, and all tax receipts must be deposited with central treasury offices in the provinces (see also Vaillancourt, 2001). ${ }^{8}$ Policy is supposed to be executed through central government administrators appointed to the provinces-for example, the Ministry of Finance is responsible for mobilizing resources through offices in the center and provinces. The reality is very different. Lao P.D.R. in fact operates a system of "upward revenue sharing" in which

\footnotetext{
${ }^{7}$ In a deconcentrated system, provinces have little autonomy. Policy is executed through central government administrators appointed to the provinces. A decentralized system, on the other hand, involves direct management of a number of public services at the local level by local authorities, and the transfer of resources and decision making powers to lower-level authorities (who are largely independent of higher levels of government).

${ }^{8}$ Prime Ministerial Decree No.192, 1999.
} 


\section{Box 1. Recent History of Decentralization in Lao P.D.R. ${ }^{9}$}

Historically, local governments have enjoyed considerable autonomy in Lao P.D.R. Traditionally, the core political entity was the meuang (or district). Smaller meuangs were nested into regional meuangs, which were led by princes from aristocratic families. Although all the regional meuangs accepted the king of the Lao kingdom as the sovereign, the regional meuangs were extremely powerful.

Since the formation of Lao People's Democratic Republic in 1975, all political power has been vested in the Lao People's Revolutionary Party. The Party permeates and controls the government, bureaucracy and the military at both central and provincial levels. In each province, power is vested in the hands of governors, who are Party members and hold ministerial ranks. The central authority is composed of the Party Central Committee, the Government and the Supreme People's Council. Even when the party attempted to establish a centrally planned economy after independence, much of the country was only loosely connected to the center, and the governors used their discretion to adapt central instructions to the local context.

In 1986, a "New Economic Mechanism" was introduced, which reflected an overt policy of decentralization and led to substantial devolution of power to the provinces. The central government largely ceded control over the management of resources in the provinces. Provincial tax administrations no longer had direct communications with the central Tax Department in Vientiane. The provincial governments were permitted to conclude trade agreements with bordering foreign states. Even the State bank was decentralized, with branch managers appointed by local authorities, and the banks even set their own exchange rates in each province. By triggering a collapse in government revenues and a large increase in the budget deficit, these reforms led to a period of severe macroeconomic instability.

To address these problems, a new Constitution was introduced in 1991 which sought to reassert central control over fiscal management. The new constitution, which laid the foundation for the first national budget, was based on the concept of a unitary "deconcentrated state". In the deconcentrated system, government policy was to be implemented by administrators appointed in the provinces. However, this attempt to recentralize did little to reduce the authority of the provincial governors, which if anything was strengthened by the abolition of provincial people's councils, which had been a forum for popular participation in local government.

Towards the turn of the century, there was a new move towards decentralization with the adoption of the Prime Ministerial Decree 01 on March 11, 2000. The stated objective of the decree was to "establish provinces as the strategic unit, districts as the budget planning unit and villages as the implementing unit". The decree was meant to develop a "bottom-up" approach to budget planning, with the center retaining control over budget execution. In practice, many of the most powerful provinces interpreted the decree as a mandate to take on greater responsibility for revenue administration and budget management in their jurisdictions.

While it has ebbed and flowed, the central government has never had full control over budget operations in the provinces. Thus, while fiscal management is in principle based on a deconcentrated system, the system has in practice always been effectively "decentralized"-with provinces having considerable autonomy in the management of their affairs, independent of higher levels of governments.

\footnotetext{
${ }^{9}$ This section is drawn largely from Stuart-Fox (2005), Keuleers (1999) and Villaincourt (2001).
} 
provinces collect most of the revenues, transferring any "surplus" revenues upwards to the center. The main features of the system are as follows:

- Each province is assigned revenue and expenditure targets formulated in the context of the budget plan.

- Surplus provinces - i.e. those with an excess of revenues over domestic expenses - are expected to remit the surplus to the center, which can then be used to finance the center's own expenditures as well as transfers to the poorer deficit provinces.

- In theory, transfers to and from the center are supposed to be delivered according to the plan targets. This is designed to insulate the budget from fiscal performance at the provincial level.

- Surplus provinces that do not meet their target are expected to reduce their spending and maintain the transfers to the center. Similarly, deficit provinces are supposed to receive the targeted transfers from the center, regardless of their revenue performance.

11. The current fiscal structure suffers from two major weaknesses. First, provinces have little incentive to collect revenues in excess of their spending needs. Second, and more fundamentally, fragmentation of the administration of major taxes is inherently inefficient. It is also a key impediment to proceeding with major tax reforms such as the VAT, which the government plans to introduce in 2008/09, because they require a unified tax and customs administration. The chapter now discusses each of these issues in turn.

\section{Incentives}

12. In principle, the system in Lao P.D.R. includes incentives to encourage provinces to mobilize revenues. Until recently (see paragraph 15), provinces that exceeded their revenue target could use 50 percent of the excess for additional spending on projects in their provinces. While there has been some debate about the distribution of the excess-i.e., whether a 50 percent retention rate was enough of an incentive-and whether the restrictions imposed on the spending were acting as a disincentive, ${ }^{10}$ the main problem was that the plan revenue targets were overambitious. ${ }^{11}$

13. To illustrate the potential impact of overambitious revenue targets, consider the following hypothetical example. Suppose that the plan sets the revenue and expenditure targets for a province at 100 and 50 units respectively, in order to generate a surplus of 50 for the center (Case I). However, the target of 100 is very high, and the province only has a

\footnotetext{
${ }^{10}$ The excess revenue had to be spent on projects in the national plan.

${ }^{11}$ As noted in previous staff reports, this has particularly been a problem in the context of the budget plans for $2004 / 05$ and 2005/06.
} 
realistic chance of collecting 80, even with a major revenue effort. Under such circumstances, the province has little incentive to collect anything beyond 50, because any excess would have to be fully remitted to the center. It decides therefore to only collect 60 to show some effort-and transfer 10 units to the center.

Incentives for Revenue Collections in Provinces

\begin{tabular}{lrrrrrrrr}
\hline & \multicolumn{3}{c}{ Provincial Budget Target } & & \multicolumn{3}{c}{ Outturn } \\
\cline { 2 - 3 } & Revenues & Expenditures & Transfer & & Revenues & Expenditures & Transfer \\
\hline Case I & 100 & 50 & 50 & & 60 & 50 & 10 \\
Case II & 60 & 50 & 10 & & 80 & 60 & 20 \\
\hline
\end{tabular}

14. Consider an alternative case, where revenues are set more realistically (Case II). Suppose the revenue target is set at 60, reducing the planned transfer to the center to 10 units. In this case, the province has a clear incentive to put greater effort into mobilizing revenues because it can retain a portion of the excess. Both the center and province could gain if revenues are collected at the province's potential. In the example, it would collect an additional 20 above the target and keep half of the excess i.e., an extra 10, increase its spending to 60 and transfer 20 to the center. The center would thus get an extra 10 units in transfers and the province an extra 10 units for expenditure.

\section{The government has recently proposed a new bonus scheme to encourage}

provinces to mobilize revenues. ${ }^{12}$ Under the scheme, provinces would no longer be allowed to retain 50 percent of any revenues that they collect in excess of their target. Instead, they would be paid a small administration fee, ranging from $0.5-1.5$ percent, for the revenues that they collect. The new scheme would significantly scale back the incentives for revenue collections by the provinces. The center would also likely be worse off. Under the example provided above, provinces would only receive a fee of 0.4-1.2 units in Case II, the scenario where they exceed their revenue target. In Case I, where revenue effort is lower, the provinces would still receive a fee for revenues collected, lowering the transfer to the center.

\section{Tax Administration}

16. The decentralized fiscal system in Lao P.D.R. greatly impairs the efficiency of tax administration. This is particularly so as the central tax headquarters has limited authorities over the provincial offices, and has weak capacity to oversee day-to-day operations and to initiate and manage reforms of the tax system. The development of uniform, nation-wide, procedures to ensure coherent implementation of tax policy and consistent treatment of taxpayers across provinces is seriously impeded. In addition, cash

\footnotetext{
${ }^{12}$ The new scheme is described in the Minister of Finance's instructions and guidelines for the 2005/06 budget (No. 2372/MOF).
} 
management, including setting and realizing budget revenue targets, is impaired and opportunities for administrative economies of scale (e.g., through information technology) are limited. Compliance costs are also increased, especially for taxpayers with tax obligations in more than one province. There is a clear consensus in the literature that centralized tax administration of major taxes, such as customs and VAT, is appropriate for developing countries with limited institutional capacities (Ter-Minassian 1997).

17. The system is also vulnerable to tax competition among provinces to attract investment to their jurisdictions. Tax enforcement is severely undermined by ad hoc exemptions granted by provinces to promote investment in their regions. In the case of import duties, tax competition takes the form of undervaluation and misclassification of imports and in the case of domestic taxes, undervaluation of turnover and incomes. The weak compliance in provinces affects national efforts to stop revenue leakages and stalls prospects for key policy reforms e.g., implementing the VAT.

18. Most importantly, it impedes tax enforcement because there are no clear lines of authority. In addition to the difficulty of enforcing national policies (e.g., with respect to exemptions), the center has little control over treasury operations in the provinces. Thus, even though provinces are required to deposit revenue collections in central government accounts, there is evidence that surplus provinces often minimize remittances to the center by depositing revenues in bank accounts which are not under the control of the national treasury.

\section{The Way Forward}

\section{It has long been recognized that to address these weaknesses a centralized} administration of key taxes such as customs and turnover needs to be established. However, in order to put a centralized revenue administration in place, provinces will need to be convinced to give up their revenue collection powers. This will require a credible revenuesharing mechanism, built on an appropriate framework for revenue and expenditure assignments. The next section discusses how two of Lao P.D.R.'s neighbors, China and Vietnam, tackled this challenge.

\section{Regional Experience: China and Vietnam}

20. This section seeks to draw lessons from the reforms undertaken by China and Vietnam. China and Vietnam offer potentially useful models because they launched successful reforms in the last decade to overcome similar challenges to those faced by Lao P.D.R. ${ }^{13}$ In particular, both countries have made substantial progress in raising their revenue effort (Figures 2 and 3). These countries are also known to be models that the Lao P.D.R. authorities are looking closely to for guidance on their reform agenda.

\footnotetext{
${ }^{13}$ Prior to the reforms, both countries faced problems associated with a decentralized revenue administration. To mobilize revenues, China launched a reform program in 1994, and Vietnam in 2000.
} 
Figure 2. China: General Government Revenues, 1985-2004

(In percent of GDP)

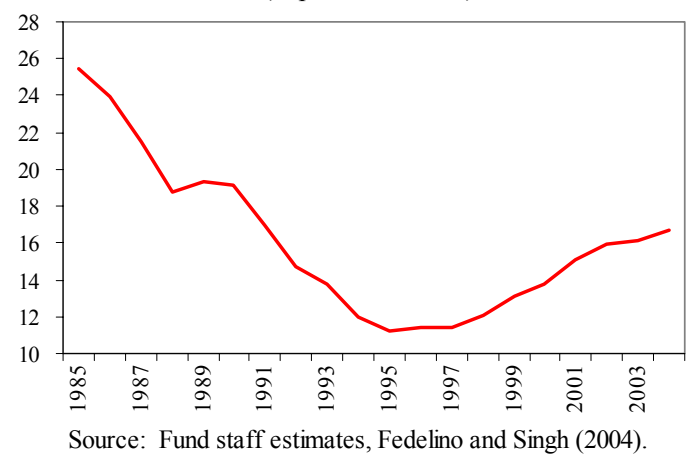

Figure 3. Vietnam: General Government Non-Oil

Tax Revenue, 1998-2004 (In percent of GDP)

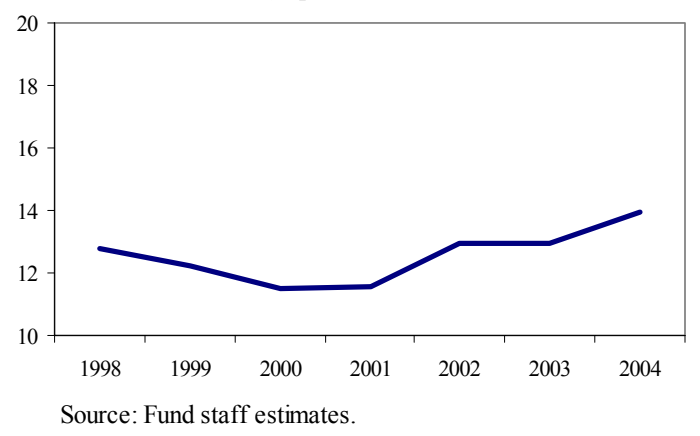

21. The discussion focuses on the following key elements of the China and Vietnam models: (i) establishing a clear assignment of revenues between the center and provinces, (ii) giving the center the authority to administer central and shared taxes, and (iii) introducing a revenue-sharing mechanism.

\section{Revenue Assignments and Tax Administration}

22. One common element to these two models is that there is an unambiguous decentralized structure with a clear assignment of revenues. In both China and Vietnam, customs duties are China and Vietnam assigned to the central government, real estate and property taxes are local revenues, and other taxes such as the VAT, personal and corporate income taxes are shared between the center and provinces. This assignment of revenues is broadly in accordance with Clear Revenue Assignment international best practices.

23. In both China and Vietnam, all major taxes are centrally administered. In China, the State Tax Administration collects all central and shared taxes, with local governments confined to administering local taxes. Vietnam goes one step further, as the central government is responsible for all tax collections. The General Taxation Department collects all taxes through a network of offices in the provinces, while the Customs Department collects all taxes on imports. In order to make it incentive-compatible for central bureaucrats to mobilize and collect local revenues, provincial authorities in Vietnam provide bonuses to tax administrators who deliver strong revenue performances. 


\section{Revenue Sharing}

\section{Both countries have adopted revenue-sharing arrangements which struck a} delicate political balance. On the one hand, the revenue-sharing arrangements should ideally be resource equalizing - i.e., the arrangements should attempt to minimize resource imbalances between provinces. However, the arrangements also need to be sufficiently attractive to the richer, more powerful provinces, to ensure adequate support for the reforms. At the very least, the reforms needed to ensure that no province was worse off as a result of the reforms. China and Vietnam handled this matter in two different ways.

25. China opted for a rules based revenue sharing system. The system provides clear rules for allocating shared taxes. For example, 75 percent of VAT and 60 percent of personal and corporate income taxes accrues to the center. At the same time, the revenue sharing rules were accompanied by a system of transfers which guaranteed that no province would have lower revenues post-reform than under the pre-reform system. This was subsequently enhanced, under the so-called "revenue returned" system, which guaranteed provinces a fixed share (30 percent) of any additional revenue raised since the start of the reforms in 1993. ${ }^{14}$ In addition to the above, the reforms introduced rules-based general-purpose grants to ensure that each province had adequate resources, and specific purpose grants which were designed to meet policy purposes in the provinces.

26. The reforms in China were very successful in mobilizing additional revenue. Revenues quickly recovered from the trough in the mid-1990s, and the center's share surged to above 55 percent - more than twice the level registered just before the reform. However, the system has come in for some criticism for being unduly regressive (e.g., see Fedelino and Singh, 2004). In particular, it has been argued that the system of revenue returned, combined with the allocation of special purpose grants, resulted in the persistence of substantial disparities in resource allocations between rich and poor provinces. The experience of China highlights one of the risks of moving to a rules-based system, namely that any design flaws could become entrenched and difficult to reverse.

27. Vietnam has taken a different approach to China, and has a revenue sharing system that is similar to Lao P.D.R. ${ }^{15}$ The revenue transferred from provinces to the center is based on the gap between provinces' expenditure needs and revenue capacity. If provincial revenue $^{16}$ is less than targeted, expenditure is reduced, keeping the transfer to the center unchanged. Provinces keep a portion of any collections above their revenue target - the retention rate varies from province to province- - with the balance of the excess remitted to

\footnotetext{
14 The "revenue-returned" system significantly slowed any changes in the pre-1993 distribution of revenues across provinces.

15 The discussion of fiscal arrangements in Vietnam draws largely on World Bank (2005).

${ }^{16}$ Provincial revenue is defined as the pool of local and shared taxes collected in the province.
} 
the center. However, there are two important differences between the operation of the Lao and Vietnamese systems:

- The revenue transfers in Vietnam are fixed for a three to five year period (the "stability" period). The amount of the transfer is determined by assigning each province a unique revenue sharing rate, which is based on the gap between the provinces' projected expenditure needs and revenue capacity. This revenue sharing rate is then applied to the provinces' revenue targets over the stability period. The stability of the revenue transfers gave provinces comfort that they would not be penalized if they over-performed on their revenue targets. ${ }^{17}$

- The revenue transfers in Vietnam were deliberately based on conservative revenue targets. Given that provinces retain a certain proportion of excess revenue collections, lowering the provincial revenue targets helped make the system incentive-compatible for provinces to collaborate with the center in mobilizing revenues.

28. While the Vietnamese system is potentially more equitable, it is less transparent and more difficult to administer. The main advantage of the Vietnamese system is that it is more flexible, and consequently better adapted to addressing income disparities between provinces. The flexibility derives from the fact that the revenue sharing rates can be tailored to the specific circumstances of the provinces. However, the system is significantly less transparent than the rules-based arrangement in China, as there is considerable scope for discretion in determining the level of the revenue sharing rates (and the revenue targets). This lack of transparency can give rise to uncertainties regarding revenue collections and governance concerns. The system is also significantly more complicated to administer effectively, an important consideration given Lao P.D.R.'s capacity constraints.

\section{Lessons for Lao P.D.R.}

29. There are several potential lessons that Lao P.D.R. can draw from the intergovernmental fiscal systems in China and Vietnam. The main lesson is that an effective decentralized fiscal system has to be based on a clear assignment of revenues, with major taxes administered by the central government. There also needs to be a credible revenue-sharing mechanism to give provinces confidence that they will have a reliable source of income to meet their expenditure needs. The design of the revenue-sharing arrangements (and associated mechanisms for allocating grants) is the most difficult element of the reforms as it has to balance two conflicting needs, namely to: (i) effect a resource transfer from richer-to-poorer provinces to ensure an equitable distribution of national resources; and (ii) ensure support from richer, more powerful, provinces, without which any reform is unlikely to succeed. As noted above, China and Vietnam approached the design of revenue-sharing arrangements in different ways, with each having their strengths and

\footnotetext{
${ }^{17}$ In contrast, under the Lao system, there is a risk that if provinces perform well, the center might demand an increase in the surplus that they transfer in subsequent years.
} 
weaknesses. International best practice suggests that, on balance, a rules-based mechanism would be more appropriate for Lao P.D.R. However, the experience in China suggests that great care should be taken in the design of the rules.

\section{E. Conclusion}

30. Progress in fiscal reforms, especially with regard to revenue mobilization, will require a broader reform of center-province fiscal relations in Lao P.D.R. This reflects the fact that the current system of "upward-revenue" sharing, with provinces responsible for collecting major taxes, is inherently incompatible with an efficient tax administration. These incompatibilities will come increasingly to the fore as Lao P.D.R. moves towards its goal of introducing a VAT. However, it is also recognized that, given Lao P.D.R.'s historically powerful provinces, moving towards a centralized or deconcentrated fiscal system will be difficult. The focus therefore needs to be on establishing a robust decentralized fiscal system.

31. The experience in China and Vietnam offers some important lessons, but reform will require a more comprehensive analysis of the decentralization framework in Lao P.D.R. and ultimately need to be based on a political consensus. The main pillars of the reform - clear revenue assignments and centralizing the administration of major taxesare relatively uncontroversial. The more difficult challenge will be to design a revenue-sharing mechanism that meets the conflicting needs of richer and poorer provinces. While international experience can offer useful guidance on how to proceed, the allocation of public resources between the center and provinces and among the provinces will ultimately need to be the product of a national political consensus. In this regard, the government's intention to start a dialogue with provinces on reforms to inter-governmental fiscal relations is welcome.

32. In the interim, there are some steps that the government could take to foster greater collaboration with the provinces. In particular, the government could offer the provinces a "quid pro quo". In return for greater incentives - primarily through setting more realistic revenue targets - the provinces could be asked to work with the central government to strengthen tax administration in their jurisdictions. In the customs area, they would need to accept greater oversight by the Customs Department in the running of the major customs posts, along the lines envisaged in the new Customs Law. On the tax side, the priority would be to help the central government re-establish a tax identification number system in the major provincial tax offices, which would form the basis of a new tax reporting system. 


\section{References}

Ahmad, E., L. Keping, T. Richardson, and R. Singh, 2002, "Recentralization in China?”, IMF Working Paper No. 168 (Washington: International Monetary Fund).

Fedelino, A. and R. Singh, 2004, "Fiscal Federalism," in E. Prasad, China's Growth and Integration into the World Economy, Prospects and Challenges, IMF Occasional Paper No. 232 (Washington: International Monetary Fund).

Keuleers, P., 1999, "Central-Local Relations in the Lao People's Democratic Republic: Historic Overview, Current Situation and Trends," in M. Turner, Central-Local Relations in Asia-Pacific: Convergence or Divergence, (London and New York: Macmillan and St Martins).

Rao, M. Govinda, 2003, "Fiscal Decentralization in Lao PDR,” UNDP, mimeograph.

Stuart-Fox, M., 2005, "Politics and Reform in the Lao People's Democratic Republic," Asia Research Center Working Paper No. 126 (Perth: Murdoch University).

Ter-Minassian, T., 1997, Fiscal Federalism in Theory and Practice, (Washington: International Monetary Fund).

Villaincourt, F., 2001, "Fiscal Decentralization in Lao PDR: Principles, Practices and Prospects in 2001", SIDA, mimeograph.

World Bank, 2005, Chapter 6, Draft Public Expenditure Review, pp.75-95. 


\section{THE REFORM OF THE LAO BANKING SYSTEM ${ }^{1}$}

\section{A. Introduction}

1. Over the past decade, the Lao government has undertaken several efforts to restructure and reform the banking system. Most recently, in 2001, the government launched a comprehensive bank reform program with the support of the international community. This reform program, which is still ongoing, sought to address long-standing weaknesses in the state-owned commercial banks (SCB), as well as some of the broader issues related to establishing an effective banking system.

2. Some progress has been made in strengthening the internal organization and credit appraisal procedures of the SCBs, but many challenges remain. In particular, the financial condition of the SCBs is still precarious, and progress in establishing effective governance structures for the banks has been slow. Much work also remains to be done to set up an effective bank supervision system and to create a supportive environment for the development of the banking system.

3. The paper is organized as follows: Section B explores endemic problems in the Lao banking system. Section $\mathrm{C}$ describes the broad objectives of the banking restructuring program. Section D assesses progress under the restructuring program. Section E concludes with a discussion of some of the challenges that remain.

\section{B. The Lao Banking System}

4. The Lao financial system is shallow and under-developed. The level of monetization - the ratio of broad money-to-GDP is only 18 percent-is lower than in most IDA countries, and the banking system is small with assets of around $\$ 630$ million (25 percent of GDP). The banking system is dominated by two state-owned commercial banks, which account for just over half of the assets of the banking system. ${ }^{2}$ There are three private domestic banks, and several branches of foreign banks - mainly Thai — which are permitted to operate only in Vientiane. The weak banking environment has so far limited foreign bank activities mainly to trade finance, and they are not well integrated into the economy.

5. Earlier attempts to restructure the SCBs in the 1990s met with limited success. After the break-up of the monobank system in 1988, the newly created SCBs quickly ran into financial difficulties, and by the early 1990s they were deeply insolvent, weighed down by non-performing loans inherited from the monobank and continued state interference in their

\footnotetext{
${ }^{1}$ Prepared by Shinichi Nakabayashi (ext. 38918) and Renuka Vongviriyatham (World Bank).

2 Banque Pour Le Commerce Exterieur Lao (BCEL) and Lao Development Bank (LDB). Until recently, the Agricultural Promotion Bank (APB), which accepts deposits, has acted primarily as a development bank. However, APB is being transformed into a market-oriented rural finance institution, with support from the Asian Development Bank (AsDB), and the bank has recently been made subject to the same prudential requirements as other commercial banks.
} 
operations. In 1994, the government decided to recapitalize SCBs, at a cost of around 2 percent of GDP. However, the recapitalization was not accompanied by any operational restructuring — or a reduction in state interference — and by the end of the decade, all the SCBs were once again deeply insolvent and heavily burdened by non-performing loans. ${ }^{3}$

6. The failure to make greater progress, reflected a number of endemic problems. These included, most notably:

- Inadequate governance. Credit decisions by the SCBs have historically been susceptible to pressure to extend credits based on political or social criteria, rather than financial viability.

- Low capacity. The lack of skilled personnel hampered, in particular, efforts to build up credit appraisal and risk-management capacity at the SCBs.

- Poor supervision. Inadequacies in banking regulations and the supervisory capacity of the Bank of Lao P.D.R. (BOL) hindered prudential oversight of the banks. The BOL also had difficulty establishing itself as an independent bank supervisor, separate from the banks' management.

\section{In addition, weaknesses in public sector management had a major impact on} the SCBs. In the 1990s, the banks' main problem was directed lending to state-owned enterprises (SOE). Although the SOE sector is relatively small in Lao P.D.R., SOEs were a major source of non-performing loans in the 1990s (and 1980s). ${ }^{4}$ The persistent recurrence of non-performing SOE loans reflected mainly the absence of a repayment culture, state interference in pricing and protracted weaknesses in their operations. Government arrears to contractors on public projects were also a significant problem, as these contractors subsequently defaulted on their loans to the SCBs.

8. Reform efforts were also hampered by a poor banking environment. The main problems were a weak legal framework and a poor credit culture (which extended beyond the SOEs). Weaknesses in the legal regime, especially with respect to contract enforcement, made the resolution of non-performing loans very difficult. Even after the court ruled in favor of the creditor, asset recovery was slow and uncertain, because the rulings were not always enforced. This clearly undermined the incentive for creditor discipline. The lack of competition has also been a major constraint on the development of a modern banking system. In addition to the poor banking environment, new entrants into the banking system

\footnotetext{
${ }^{3}$ By 2001, three quarters of BCEL's loans were non performing and the bank had a capital deficit of 4 percent of GDP. The financial position of the Lane Xang Bank and Lao May Bank, which were merged to form LDB in 2003, was equally poor. Over 60 percent of their loans were non-performing and the banks had a combined capital deficit of 2 percent of GDP.

${ }^{4}$ The Ministry of Defense conglomerate Phoudoi accounted for 40 percent of the SCBs' non-performing loans in the late 1990s.
} 
have been discouraged by restrictions on the opening of branches outside of Vientiane, and a SCB monopoly on all natural resource-related banking activities. ${ }^{5}$

\section{Bank Restructuring Program}

9. The government's bank restructuring program aimed to restore the financial integrity of the SCBs and develop a market-based banking system. To this end, it had three main objectives: (i) restructuring the SCBs; (ii) strengthening bank supervision; and (iii) improving the overall banking environment. ${ }^{6}$ The program was to be implemented in parallel with an SOE reform program to stem the level of non-performing loans from this source.

\section{Restructuring the SCBs}

\section{The restructuring plans aimed at putting the SCBs on a sound commercial} footing, with particular emphasis on reducing the level of non-performing loans. Such loans were divided into "stock" (up to December 1999) and "flow" (since January 2000). The concept was for "stock" loans to be paid mainly by the government since they were either directed by or guaranteed by the government. To this end, the government committed to a multiyear recapitalization plan that would be conditional on progress on the restructuring of the SCBs. However, the main emphasis was on improving the quality of the new loans extended by the SCBs. To this end, the government (and BOL) committed to ceasing directed lending, to enable the SCBs to base their new credit decisions on commercial criteria.

\section{Implementation of the restructuring program was slower than originally} envisaged. The program did not begin until 2003 when the program was formalized, with each SCB committing itself to a restructuring agenda set out in formal Governance Agreements cosigned by the Ministry of Finance and the BOL. ${ }^{7}$ The delay was costly, as the SCBs continued to extend noncommercial loans and to make losses during 2002, resulting in a further deterioration in their financial position.

\section{The Governance Agreements called for the enforcement of a restricted lending} regime to stop loss making activities if credit quality deteriorated. The restricted lending regime was designed to limit new lending until sound operational policies and procedures were put in place. A key feature of the regime was that SCBs whose net flow NPLs rose above 15 percent would be prohibited from increasing their risk portfolio. Each SCB was assigned a limited amount of notional capital to ensure that it could continue operations

\footnotetext{
${ }^{5}$ For example, all mining projects have to bank with the SCBs.

${ }^{6}$ The program also included a fourth objective: promoting rural and micro finance. The AsDB has actively supported this.

${ }^{7}$ Although the BOL issued several notices, instructions, and regulations to limit the deterioration of the SCBs' asset quality during 2001 and 2002, strict limits on loan growth were not enforced until a restricted lending regime came into force in early 2003.
} 
within the existing banking regulations, despite their severe capital deficiency. New lending to defaulted debtors was also prohibited. New off-balance sheet exposure had to be secured by cash deposits or issued against confirmed export letters of credit. Credit approval was to be recentralized from branches to headquarters, with the credit approval ceiling being set for each branch.

\section{Two long-term international banking advisors for each SCB were recruited by} the BOL to assist with the restructuring of the SCBs. They were to focus on the development and implementation of better credit policies and procedures, the formation of new organizational and committee structures, and the implementation of new operating guidelines. Credit review committees were to be established in the SCBs and the advisors were to be mandated to review and certify large loan proposals and to issue "compliance certification" if loan proposals were in full compliance with the procedures of the credit approval process and met sound commercial criteria. However, their advice and certification were not binding.

\section{Bank Supervision}

14. The second aim of the program was to strengthen supervision and regulation of the banking system. Prudential regulations on loan classification, provisioning and foreign exchange exposure were to be introduced and enforced. The program was to be supported by technical assistance from the Fund, to strengthen the central bank's technical capacity, especially for on-site examinations and off-site monitoring.

\section{Overall Banking Environment}

\section{The program also aimed to develop the financial system by increasing} competition and improving the banking environment. Restrictions imposed on the banking operations of non state-owned commercial banks were to be abolished, and the banking laws were to be amended to provide for a level playing field.

\section{Legal and judicial reforms to facilitate financial intermediation and the} resolution of non-performing loans were also envisaged. Commercial courts were to be established to rule on cases involving disputes between creditors and debtors over loan and security contracts. Legislation was to be reformed to strengthen laws related to bankruptcy, secured transaction, and leasing. The rule of law was to be strengthened to better protect creditor rights and thus increase the number of bankable projects. Accounting standards were to be upgraded gradually to international standards.

\section{Assessment of Progress}

\section{Financial Condition of the SCBs}

17. The SCBs remain in a very weak financial condition, but there is some evidence that the Governance Agreements were starting to have a positive impact. In particular, the restricted lending regime that was put in place in April 2003 appears to have had a positive impact on the risk profile of the banks. The regime sharply scaled back new lending 
activities by the banks, especially to SOEs, and increased the banks' focus on recovering non-performing loans. There was also an effort to improve the banks' profitability.

\section{However, there are concerns that these initial positive trends may not be}

sustained. In April 2004, the authorities lifted the restricted lending regime and gave the SCBs greater scope to resume lending. There was also a decision to reduce the complement of international banking advisers to allow the banks" managements to "stand on their own feet." Credit growth has since accelerated and there is renewed evidence of directed lending - most notably to a large domestic cement project in the south of the country. Recent audit reports have cautioned that rapid credit growth in these circumstances could lead to a further deterioration of the financial position of the SCBs.

\section{(a) Asset Quality}

19. Recent audit reports suggest that the SCBs have made some progress in improving the quality of their new lending, especially at BCEL. The level of non-performing loans on new credits approved since end-2002 has fallen to less than 2 percent at BCEL. The improvement at LDB has been less strong - the NPL ratio is still relatively high at 12 percent - and the evidence from other indicators, such as overdue loans, suggest that this may rise significantly in the future. As noted below (paragraph 22), the use of local accounting standards may also understate the true extent of the NPLs.
Quality of New Lending by BCEL and LDB

\begin{tabular}{lrrr}
\hline & $\begin{array}{c}\text { New Loans 1/ } \\
\text { (billions of Kip) }\end{array}$ & $\begin{array}{c}\text { NPLs } \\
(\%)\end{array}$ & $\begin{array}{r}\text { Overdue 2/ } \\
(\%)\end{array}$ \\
\hline BCEL & & & \\
$\quad$ - as of Dec 03 & 118.7 & 1.1 & 9.5 \\
- as of Dec 04 & 199.4 & 2.4 & 13.7 \\
- as of Jun 05 3/ & 397.9 & 1.4 & 5.8 \\
LDB & & & \\
- as of Dec 03 & & & \\
- as of Dec 04 & 75.5 & 2.4 & 14.8 \\
- as of Jun 05 3/ & 224.3 & 9.4 & 18.7 \\
& 239.9 & 12.0 & 28.2 \\
\hline
\end{tabular}

Source: BCEL, LDB and Audit reports.

1/ Since end-2002.

2/ Less than 90 days.

3/ Unaudited.

20. There is also some evidence that the SCBs have exercised greater discipline in their lending to state-owned enterprises. Although SOE credits continue to account for a large share of BCEL's loan portfolio (43 percent), the bulk of these loans have been carried over from the 1990s. New lending to SOEs has been sharply scaled back, and the management of the bank report that they no longer lend to insolvent enterprises. LDB's exposure to SOEs is limited, amounting to less than 2 percent of its portfolio.

21. There were also increased efforts to resolve NPLs, especially at LDB. In 2003, BCEL and LDB, with the assistance of their international advisers, formulated a strategy to resolve their largest NPL accounts. The strategy met with some success. Between 2003 and 2004, LDB collected over kip 100 billion in cash from NPL accounts, with a further kip 34 billion settled through the issuance of government triangular bonds. ${ }^{8}$ LDB also

\footnotetext{
${ }^{8}$ The bonds are designed to settle arrears between the government, suppliers, and the SCBs.
} 
wrote-off over kip 100 billion of NPLs in 2003, in an effort to clean its books. Progress at BCEL was more limited, perhaps reflecting the fact that the accounts were larger and more intractable. Cash collections on NPLs amounted to only kip 21 billion between 2003 and 2004, although a further kip 84 billion were resolved through the issuance of triangular bonds.

22. However, the total stock of NPLs remains very high. The total NPL ratio of BCEL was estimated at around 80 percent in 2004, and the bank's external auditors suggest that if the full IFRS ${ }^{9}$ standards were used, the ratio would be closer to 95 percent. Similarly, for LDB, while the audits report that the NPL ratio had fallen to 32 percent at end-2004, the ratio would be closer to 90 percent, if the stricter IFRS standard is used.

\section{(b) Earnings}

\section{While the banks have taken some steps to improve their profitability, their} earnings are still weak, because a large share of their assets are non-performing. After declining between 2001 and 2003, ${ }^{10}$ BCEL reported an increase in its operating profit in 2004. The turnaround reflected partly the introduction of a new fee structure, as well as a rebound in net interest income following a pick-up in loan growth and a reduction in deposit rates. While there was some improvement in its net interest income in 2004, the LDB has continued to operate at a loss. In addition to weak net interest income, due to a high level of non-performing assets, the bank's profitability has also been weakened by a sharp rise in operating expenses between 2001 and 2003.

\section{(c) Capital}

\section{Both banks remain}

highly insolvent. At end-2004, the combined capital deficit of

the two SCBs was estimated at kip 900 billion (4 percent of GDP). The slow progress in reducing the capital shortfall under the program largely reflects delays in the implementation of the phased recapitalization envisaged under the program, which has yet to commence. The delays reflected a reluctance by the Ministry of Finance to proceed with the recapitalization plan because of the slow progress in the operational restructuring of the banks.

\footnotetext{
${ }^{9}$ International Financial Reporting Standards.

${ }^{10}$ The decline in profit partly reflected lower interest income due to an increase in non-performing loans, as well as a sharp decline in fee income.
}

Lao P.D.R.: Capital and Assets of BCEL and LDB

\begin{tabular}{lrrrr}
\hline & 2001 & 2002 & 2003 & 2004 \\
\hline BCEL & & & & \\
Capital & -626 & -684 & -610 & -572 \\
Total Assets & 1,290 & 1,631 & 1,618 & 2,029 \\
Capital to Total Assets (\%) & -49 & -42 & -38 & -28 \\
& & & & \\
LDB & & & & \\
Capital & -242 & -308 & -320 & -329 \\
Total Assets & 611 & 739 & 946 & 1,055 \\
Capital to Total Assets (\%) & -40 & -42 & -34 & -31 \\
\hline
\end{tabular}

Source: Audit reports. 
Lao P.D.R.: Operating Profit of BCEL 1/

(In millions of U.S. dollars)

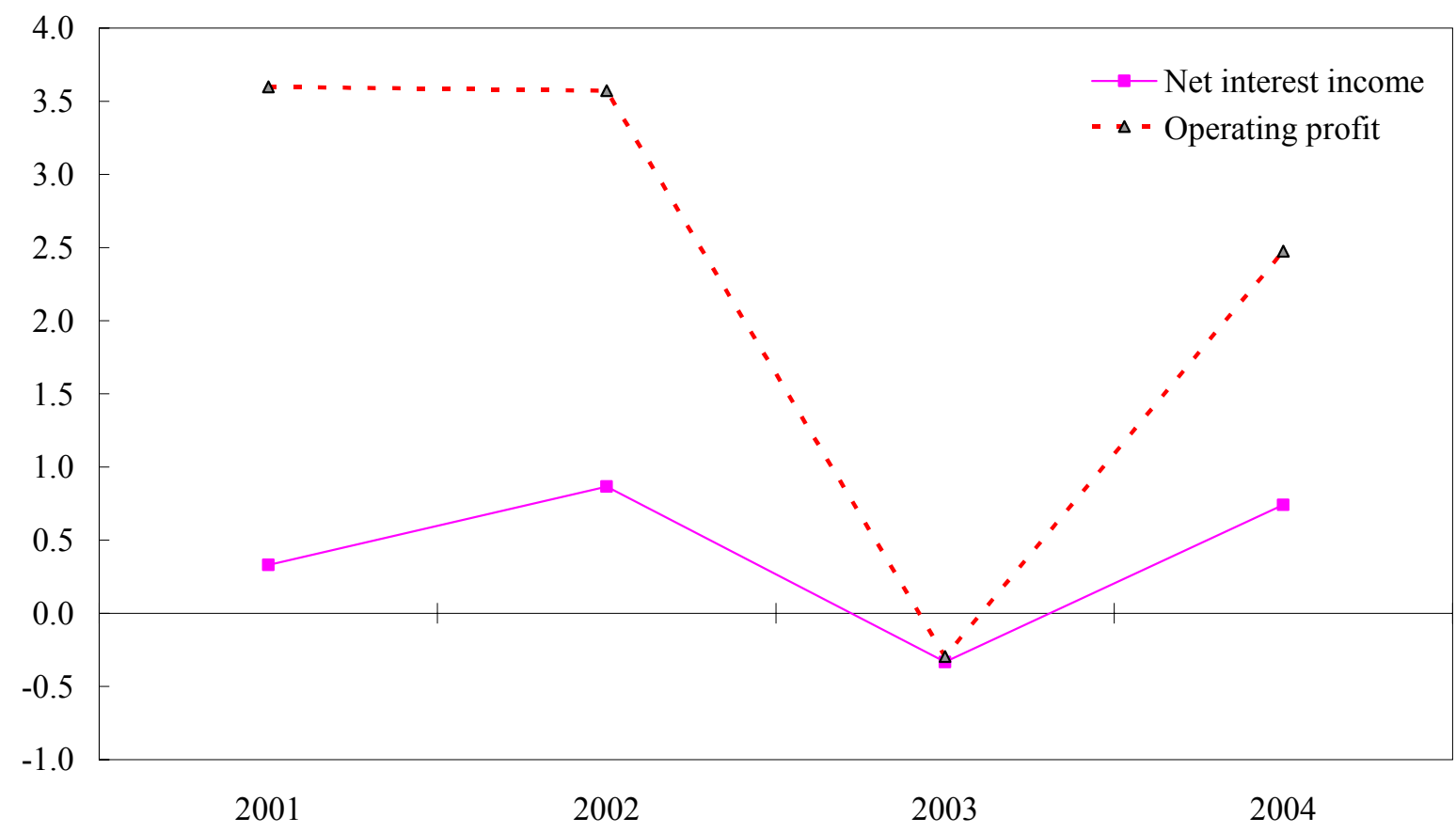

Lao P.D.R.: Operating Profit of LDB 1/

(In millions of U.S. dollars)

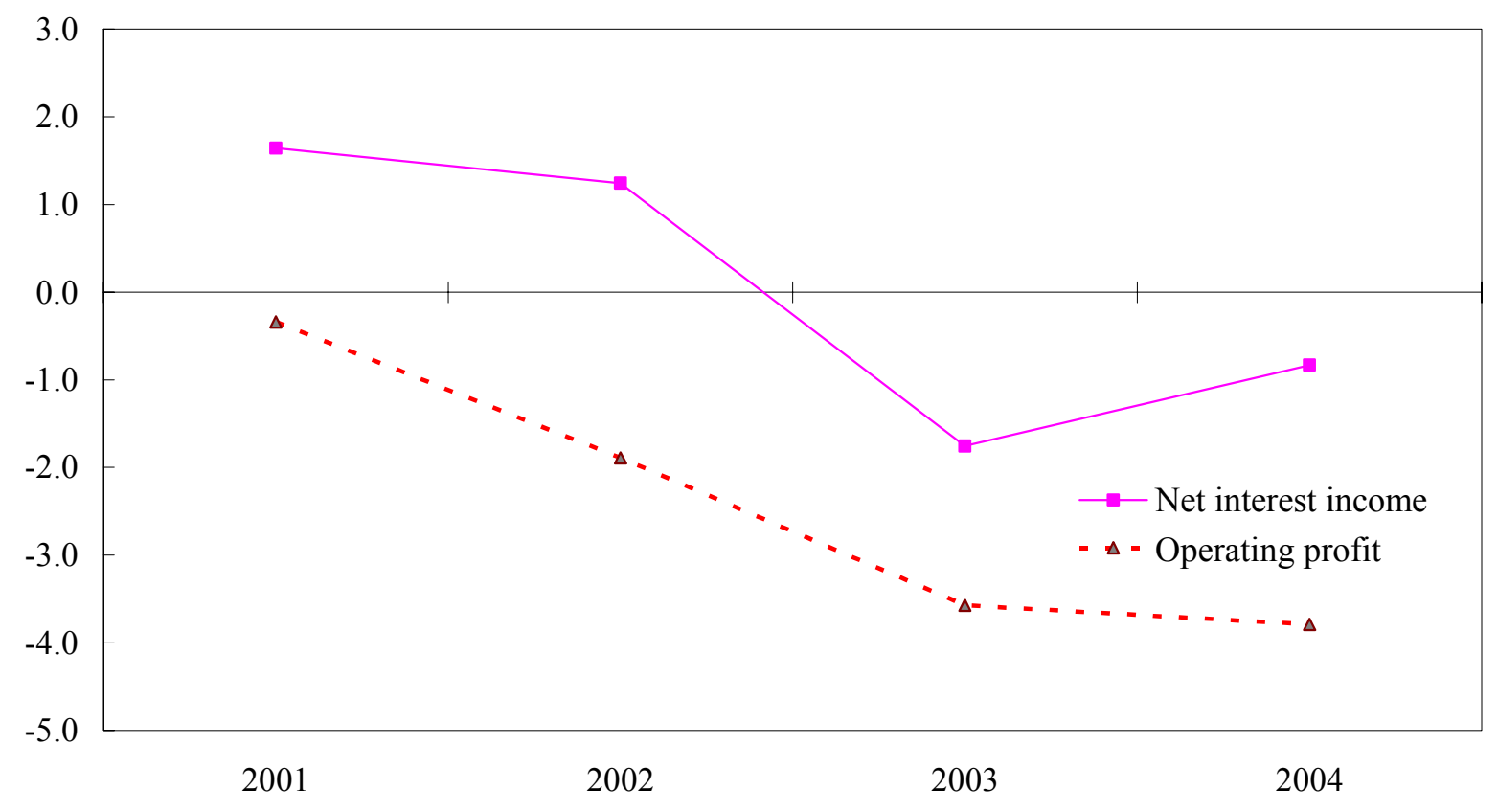

1/ Excludes provisioning. 
25. The 2004 audit estimated that a capital injection of kip 1,200 billion (5 percent of GDP) would be needed to give the two SCBs a capital adequacy ratio of 8 percent. In August 2005, the government decided to initiate the process of recapitalizing the banks. The plan is to provide the banks with new capital of kip 634 billion-mainly in the form of bonds - in four tranches between 2005 to 2008. The first tranche of kip 200 billion, which was originally scheduled to be disbursed in September 2005, is expected shortly. The expectation is that the balance of the banks capital requirements will be met through accelerated recoveries on non-performing loans and by retained earnings as the SCBs increase their profitability.

\section{Restructuring the SCBs}

26. The authorities have made some progress in restructuring the two SCBs. In 2003, the two smaller SCBs, Lao May Bank and Lane Xang Bank were merged to form the LDB, and the new bank's branch and staff structures have been streamlined. At BCEL, a management information system has been installed, improving communication between the branches and headquarters. Both banks have introduced new policies, with the help of the international banking advisers, to strengthen the credit appraisal and approval process and improve treasury management. The introduction of a certification process, whereby the international advisers formally review large loan proposals, has also had a positive impact on the quality of lending.

27. However, the Governance Agreements have come in for some criticism. The main criticism is that the agreements focused more on processes than quantifiable improvements in performance. Moreover, the financial benchmarks that were included - e.g., with regard to the recapitalization of the banks - were overambitious, especially as they were not backed by a consensus within government.

28. The government is in the process of drawing up revised governance agreements with the assistance of the AsDB. These agreements will seek to streamline the management structure of the banks to make managers more accountable and are expected to put greater emphasis on concrete improvements in financial performance. The international advisers will be given expanded responsibility for monitoring performance against the financial benchmarks. However, it is recognized that ultimately, progress in the restructuring of the banks will depend on the ownership and commitment to reform by the authorities, which is yet to be fully established.

\section{Bank Supervision}

29. The authorities have also made some progress in strengthening bank supervision, but much remains to be done. New regulations were issued in 2004 on foreign exchange exposure to ensure that banks maintained their exposure within prudential limits. Regulations were also issued on loan classification to ensure that banks consistently review and classify loans and set aside provisioning expenses. However, the enforcement of the new regulations has been slow. The bank supervision department has also sought to strengthen its on- and off-site supervision of banks, with the assistance of an IMF adviser. On-site inspections of SCB branches outside Vientiane have been undertaken, as well as of some 
private banks - although the focus of the latter has been mainly on the better-managed foreign bank branches. However, the effectiveness of the BOL's supervisory activities continue to be weakened by severe capacity constraints and a lack of clarity about its role as an independent supervisor (paragraph 37).

\section{Overall Banking Environment}

30. The current regulatory framework does not provide the Lao banking sector with a level playing field. While the government's stated policy is to promote a level playing field, there are still significant obstacles to the effective participation of private domestic and foreign banks in the banking system. The proposed amendments to the Banking Law, which aim to reduce barriers to entry and competition from non-SCBs, have not been enacted. In addition to the regulatory forbearance granted to the SCBs, foreign banks are restricted from expanding their branch network and are required to deposit 25 percent of their capital with the BOL with no interest. The presidential decree governing the management of foreign exchange and precious metals requires mining companies to hold bank accounts only with SCBs. The SCBs are, accordingly, still protected from the competitive pressures from nonstate banks that could motivate them to improve their efficiency.

31. The authorities have taken some steps to strengthen the banking environment. Commercial courts have been established, and the SCBs have referred some cases to the courts. However, court procedures are slow, and the new institutions have had little impact on the credit culture. The Secured Transactions Law has been passed to expand the eligible loan collateral, but implementing regulations are yet to be drafted.

\section{E. Challenges Ahead}

32. There are three main challenges ahead to restructure the SCBs and strengthen the banking system: (i) improving the corporate governance of the SCBs; (ii) strengthening bank supervision; and (iii) enhancing the general banking environment.

\section{Governance}

33. Corporate governance of SCBs is still weak, hampered by the absence of a fully independent board of directors. The line between management, the central bank, and government agencies is not clear, and the system suffers from a lack of checks and balances. Although the banks' management have focused more closely on ensuring profitability and have succeeded to some extent in improving the operating performance of the SCBs, they remain vulnerable to external pressure on important credit decisions. An additional complication is that senior staff move inter-changeably between the BOL and SCBs. This makes it difficult for the SCBs and the central bank to keep an arm's length relationship, which has negative implications for autonomy of management as well as effective bank supervision.

34. The MOF should provide effective oversight of the SCBs, as shareholder. Until recently, the MOF was not actively engaged in overseeing the SCBs. However, it has recently set up an internal team to exercise its ownership role more effectively, and is 
considering sending a representative to the board of directors of the SCBs. The MOF needs to monitor the operations of the SCBs closely to determine if the phased recapitalization of the SCBs should be implemented as scheduled. The government should also consider introducing independent directors from the private sector outside the SCBs to the boards of the SCBs. The government representative and other independent directors could employ the international banking advisors and financial benchmarks to monitor the management's performance.

35. The international advisors should continue to play an important role in the bank restructuring process. The role of the advisors could be made clearer by giving them a mandate to monitor financial benchmarks under the revised Governance Agreements. Although the bank staff's understanding of credit policies and banking business has improved with the help of the advisors, technical capacity needs to be strengthened further. One further possibility is to introduce professional management from abroad, which has proven to be very effective in some transition economies, e.g., in Mongolia.

36. The structural weaknesses in the SCBs could be overcome by introducing strategic investors to the SCBs, especially if they held a majority share. Central European countries such as Hungary and Poland ultimately succeeded in reforming their state-owned banks after a majority of shares were sold to foreign strategic investors. In China and Vietnam, foreign investment is being gradually allowed, starting with small minority stakes. In addition to strengthening the governance of the SCBs, capital and human resources also need to be reinforced.

\section{Bank Supervision}

37. The main priority is to enhance the BOL's prudential oversight of the banking system. In addition to continuing to build up the BOL's technical capacity in on- and off-site supervision, the framework of banking regulations needs to be strengthened to reduce the scope of regulatory forbearance, especially in the area of single borrower exposures. The latter is particularly important as it would help reduce the BOL's day-to-day intervention in credit decisions and help more clearly define its role as a bank regulator. ${ }^{11}$

\section{Banking Environment}

38. Steps to increase competition and provide a level playing field for all participants in the banking system are needed to support the country's economic development. The banking act and the presidential decree preventing the expansion of operations of foreign banks should be amended to promote competition and stimulate SCB reforms. The provision of a level playing field is also crucial to attract foreign direct investment in the banking sector.

\footnotetext{
${ }^{11}$ Under the current regime, SCBs have to frequently seek permission from the BOL to extend credits above a certain amount.
} 
39. Further reforms in the areas of bankruptcy, property and land laws are needed to deepen financial intermediation. Banking infrastructure including credit information, collateral registration, payment system, and inter-bank markets need to be developed. Assistance from the international community will be required to complete this agenda. The reform measures are of critical importance since the country's future development will require a well-functioning banking system. 


\section{References}

Baker, Carol, 2005, Vietnam-The Development Assistance Fund: Should We Be Concerned? IMF Selected Issues, IMF Country Report No. 06/20 (Washington: International Monetary Fund).

Fratzscher, Oliver, Rose Thomas, and Vongviriyatham Renuka, 2005, “A Preliminary Stock Taking of The Banking Sector Reform in Lao PDR" (Washington: World Bank).

Hauner, David, Shanaka J. Peiris, "Bank Efficiency and Competition in Low-Income Countries: The Case of Uganda," IMF Working Paper WP/05/240 (Washington: International Monetary Fund).

Lao, PDR, Committee for Planning and Investment, 2006, Sixth National Socio Economic Development Plan (2006-2010) (Vientiane).

Podpiera, Richard, March 1, 2006, China-Progress in China's Banking Sector Reform: Has Bank Behavior Changed?, IMF Working Paper 06/71 (Washington: International Monetary Fund).

Sidgwick, Eric, 2002, Lao PDR-The Reform of State-Owned Banks and Enterprises, IMF Staff Country Report No. 02/207 (Washington: International Monetary Fund).

Unteroberdoerster, Olaf, 2005, "Banking Reform in the Lower Mekong Countries," IMF Policy Discussion Paper PDP/04/05 (Washington: International Monetary Fund).

2001-2004 audit results for the BCEL and the LDB.

BFSD's reports (Vientiane, The Bank of Lao P.D.R.). 
Table 1. Lao P.D.R.: Real GDP by Industrial Origin, 2000-2004

(In billions of kip; at 1990 constant market prices)

\begin{tabular}{|c|c|c|c|c|c|}
\hline & 2000 & 2001 & 2002 & $20031 /$ & $\frac{20041 /}{\text { Est. }}$ \\
\hline Agriculture & 584 & 606 & 630 & 644 & 666 \\
\hline Crops & 347 & 361 & 373 & 373 & 388 \\
\hline Livestock and fishery & 202 & 207 & 217 & 227 & 234 \\
\hline Forestry & 35 & 38 & 40 & 43 & 44 \\
\hline Industry & 254 & 280 & 308 & 344 & 387 \\
\hline Mining and quarrying & 5 & 6 & 6 & 22 & 21 \\
\hline Manufacturing & 189 & 212 & 239 & 254 & 289 \\
\hline Construction & 25 & 29 & 27 & 30 & 38 \\
\hline Electricity, gas, and water & 35 & 34 & 36 & 37 & 39 \\
\hline Services & 281 & 297 & 314 & 337 & 363 \\
\hline $\begin{array}{l}\text { Transportation, storage, and } \\
\text { communication }\end{array}$ & 65 & 71 & 77 & 84 & 92 \\
\hline Wholesale and retail trade & 105 & 114 & 123 & 136 & 149 \\
\hline Banking, insurance, and real estate & 9 & 10 & 5 & 6 & 5 \\
\hline Ownership of dwellings & 33 & 34 & 35 & 36 & 37 \\
\hline Public wage bill & 33 & 34 & 39 & 40 & 41 \\
\hline Nonprofit institutions & 9 & 8 & 8 & 8 & 9 \\
\hline Hotels and restaurants & 25 & 25 & 26 & 24 & 28 \\
\hline Other & 2 & 2 & 2 & 2 & 3 \\
\hline GDP at factor cost & 1,119 & 1,183 & 1,253 & 1,324 & 1,415 \\
\hline Import duties & 8 & 9 & 10 & 11 & 13 \\
\hline GDP at market prices & 1,127 & 1,192 & 1,263 & 1,335 & 1,428 \\
\hline
\end{tabular}

Source: Data provided by the Lao P.D.R. authorities.

1/ Differ from Fund staff estimates. 
Table 2. Lao P.D.R.: Real GDP Growth, 2000-2004

(In percent)

\begin{tabular}{|c|c|c|c|c|c|c|}
\hline & $\begin{array}{r}2000 \\
\text { Weights } \\
\end{array}$ & 2000 & 2001 & 2002 & $20031 /$ & $\frac{20041 /}{\text { Est. }}$ \\
\hline Agriculture & 52.1 & 4.9 & 3.8 & 4.0 & 2.2 & 3.5 \\
\hline Crops & 31.0 & 13.2 & 4.1 & 3.5 & 0.0 & 4.0 \\
\hline Livestock and fishery & 18.1 & 2.3 & 2.5 & 4.6 & 4.9 & 3.0 \\
\hline Forestry & 3.1 & -33.6 & 8.1 & 5.1 & 8.6 & 1.3 \\
\hline Industry & 22.7 & 8.5 & 10.1 & 10.1 & 11.5 & 12.5 \\
\hline Mining and quarrying & 0.5 & 1.4 & 1.2 & 10.1 & 267.5 & -5.1 \\
\hline Manufacturing & 16.9 & 7.2 & 12.1 & 13.0 & 6.3 & 13.7 \\
\hline Construction & 2.3 & -9.2 & 13.0 & -6.5 & 12.9 & 24.6 \\
\hline Electricity, gas, and water & 3.1 & 39.0 & -1.3 & 6.3 & 1.2 & 5.3 \\
\hline Services & 25.2 & 4.9 & 5.7 & 5.7 & 7.2 & 7.5 \\
\hline $\begin{array}{l}\text { Transportation, storage, and } \\
\text { communication }\end{array}$ & 5.8 & 9.0 & 8.6 & 8.4 & 9.3 & 9.5 \\
\hline Wholesale and retail trade & 9.4 & 5.0 & 8.9 & 7.5 & 10.7 & 9.2 \\
\hline Banking, insurance, and real estate & 0.8 & -35.7 & 12.7 & -46.3 & 14.0 & -24.0 \\
\hline Ownership of dwellings & 3.0 & 2.5 & 2.5 & 2.5 & 2.5 & 2.5 \\
\hline Public wage bill & 3.0 & 7.1 & 1.6 & 15.0 & 3.4 & 1.0 \\
\hline Nonprofit institutions & 0.8 & 7.5 & -12.5 & 4.2 & 7.0 & 7.4 \\
\hline Hotels and restaurants & 2.3 & 16.5 & -1.2 & 2.7 & -5.0 & 16.5 \\
\hline Other & 2.3 & 28.9 & -1.5 & 2.6 & 8.7 & 16.1 \\
\hline GDP at factor cost & 100.0 & 5.7 & 5.7 & 5.9 & 5.7 & 6.9 \\
\hline Import duties & 0.7 & 20.4 & 15.8 & 12.6 & 8.9 & 14.5 \\
\hline GDP at market prices & 100.7 & 5.8 & 5.8 & 5.9 & 5.8 & 6.9 \\
\hline
\end{tabular}

Source: Data provided by the Lao P.D.R. authorities.

1/ Differ from Fund staff estimates. 
Table 3. Lao P.D.R.: Nominal GDP by Industrial Origin, 2000-2004

(In billions of kip)

\begin{tabular}{|c|c|c|c|c|c|}
\hline & 2000 & 2001 & 2002 & $20031 /$ & $\frac{20041 /}{\text { Est. }}$ \\
\hline Agriculture & 7,127 & 7,975 & 9,174 & 10,829 & 12,378 \\
\hline Crops & 4,233 & 4,750 & 5,439 & 6,280 & 7,216 \\
\hline Livestock and fishery & 2,468 & 2,727 & 3,156 & 3,824 & 4,350 \\
\hline Forestry & 427 & 497 & 578 & 725 & 811 \\
\hline Industry & 3,106 & 3,687 & 4,492 & 5,783 & 7,190 \\
\hline Mining and quarrying & 67 & 73 & 89 & 378 & 397 \\
\hline Manufacturing & 2,306 & 2,787 & 3,483 & 4,277 & 5,373 \\
\hline Construction & 309 & 377 & 390 & 508 & 700 \\
\hline Electricity, gas, and water & 423 & 450 & 530 & 619 & 720 \\
\hline Services & 3,330 & 3,899 & 4,554 & 5,703 & 6,785 \\
\hline $\begin{array}{l}\text { Transportation, storage, and } \\
\text { communication }\end{array}$ & 794 & 930 & 1,115 & 1,408 & 1,703 \\
\hline Wholesale and retail trade & 1,284 & 1,507 & 1,792 & 2,292 & 2,764 \\
\hline Banking, insurance, and real estate & 105 & 128 & 76 & 100 & 84 \\
\hline Ownership of dwellings & 406 & 449 & 509 & 603 & 682 \\
\hline Public wage bill & 393 & 517 & 643 & 822 & 957 \\
\hline Nonprofit institutions & 12 & 11 & 12 & 15 & 15 \\
\hline Hotels and restaurants & 309 & 329 & 374 & 423 & 528 \\
\hline Other & 26 & 28 & 32 & 41 & 51 \\
\hline Import duties & 107 & 141 & 182 & 211 & 237 \\
\hline GDP at market prices & 13,669 & 15,702 & 18,401 & 22,525 & 26,590 \\
\hline
\end{tabular}

Source: Data provided by the Lao P.D.R. authorities.

1/ Differ from Fund staff estimates. 
Table 4. Lao P.D.R.: Output of Major Commodities, 2000-2004

\begin{tabular}{|c|c|c|c|c|c|c|}
\hline Item & Unit & 2000 & 2001 & 2002 & 2003 & 2004 \\
\hline \multicolumn{7}{|l|}{ Agriculture } \\
\hline Paddy & thousand tons & 2,230 & 2,335 & 2,417 & 2,375 & 2,529 \\
\hline Corn & thousand tons & 117 & 111 & 124 & 143 & 204 \\
\hline Sweet potatoes and cassava & thousand tons & 52 & 101 & 111 & 150 & 175 \\
\hline Coffee & thousand tons & 255 & 631 & 633 & 663 & 671 \\
\hline Tobacco & thousand tons & 18 & 26 & 32 & 22 & 23 \\
\hline \multicolumn{7}{|l|}{ Livestock } \\
\hline Buffalo & thousand heads & 1,007 & 1,052 & 1,091 & 1,113 & 1,112 \\
\hline Cattle & thousand heads & 987 & 1,218 & 1,209 & 1,245 & 1,249 \\
\hline Pigs & thousand heads & 1,101 & 1,427 & 1,416 & 1,655 & 1,728 \\
\hline Goats and sheep & thousand heads & 100 & 123 & 126 & 138 & 139 \\
\hline Poultry & thousand heads & 12,028 & 14,065 & 15,275 & 19,475 & 19,481 \\
\hline \multicolumn{7}{|l|}{ Forestry } \\
\hline Logs & thousand $\mathrm{m}^{3}$ & 378 & 239 & $\ldots$ & $\ldots$ & $\ldots$ \\
\hline \multicolumn{7}{|l|}{ Industry } \\
\hline Tin & tons & 800 & 816 & $\ldots$ & $\ldots$ & $\ldots$ \\
\hline Gypsum & thousand tons & 185 & 150 & 99 & 98 & 236 \\
\hline Gold & $\mathrm{Kg}$ & $\ldots$ & $\ldots$ & $\ldots$ & 8,900 & 7,000 \\
\hline \multicolumn{7}{|l|}{ Manufacturing } \\
\hline Hydropower & million kwh & 3,678 & 3,590 & 3,603 & 3,179 & 3,347 \\
\hline Beer & thousand hectoliter & 508 & 577 & 652 & 702 & 827 \\
\hline Soft drinks & thousand hectoliter & 143 & 142 & 148 & 164 & 187 \\
\hline Cigarettes & million packs & 41 & 41 & 55 & 68 & 84 \\
\hline Agricultural tools & thousand units & 4 & 4 & 4 & 4 & 4 \\
\hline Detergent & tons & 900 & 700 & 700 & 710 & 860 \\
\hline Nails & tons & 650 & 740 & 745 & 760 & 900 \\
\hline Oxygen & thousand bottles & 21 & 21 & 21 & 21 & 23 \\
\hline Electric cord & thousand $\mathrm{m}$ & 2,000 & $\ldots$ & $\ldots$ & $\ldots$ & $\ldots$ \\
\hline Plastic products & tons & 3,850 & 4,350 & 4,420 & 4,530 & 5,500 \\
\hline Salt & thousand tons & 19 & 21 & 22 & 22 & 25 \\
\hline Wood furniture & million kip & 12,700 & 15,240 & 15,350 & 15,550 & $\ldots$ \\
\hline Rattan furniture & million kip & 275 & 320 & 345 & 350 & 430 \\
\hline Garments & million pieces & 24 & 32 & 33 & 34 & 37 \\
\hline Sugar & tons & 300 & 265 & 562 & 450 & $\ldots$ \\
\hline Tobacco & thousand tons & 1,100 & 358 & 593 & 947 & 1,897 \\
\hline Plywood & million sheets & 2,100 & 2,200 & 2,250 & 1,550 & 1,300 \\
\hline Cement & thousand tons & 75 & 75 & 263 & 280 & 282 \\
\hline Bricks & million pieces & 66 & 87 & 89 & 90 & 120 \\
\hline Wood & thousand meters & 240 & 230 & 235 & 198 & $\ldots$ \\
\hline Ventilators & thousand pieces & 400 & 465 & 320 & 330 & 340 \\
\hline
\end{tabular}

Source: Data provided by the Lao P.D.R. authorities. 
Table 5. Lao P.D.R.: Consumer Price Indices, 2001-2005

\begin{tabular}{|c|c|c|c|c|c|}
\hline & 2001 & 2002 & 2003 & 2004 & 2005 \\
\hline & \multicolumn{5}{|c|}{$($ NSC Index; December 1999 = 100) } \\
\hline January & 111.8 & 119.8 & 138.2 & 155.6 & 168.1 \\
\hline February & 112.6 & 120.7 & 139.6 & 157.6 & 168.7 \\
\hline March & 113.0 & 121.1 & 142.7 & 159.8 & 170.1 \\
\hline April & 114.8 & 123.3 & 145.3 & 162.6 & 173.0 \\
\hline May & 116.2 & 124.0 & 146.6 & 164.7 & 174.5 \\
\hline June & 116.1 & 126.7 & 147.8 & 166.4 & 175.4 \\
\hline July & 117.3 & 130.5 & 150.0 & 168.2 & 177.1 \\
\hline August & 120.0 & 135.1 & 155.2 & 169.5 & 180.6 \\
\hline September & 120.8 & 138.4 & 158.5 & 170.2 & 183.2 \\
\hline October & 120.8 & 138.1 & 158.0 & 168.7 & 184.6 \\
\hline November & 119.8 & 136.6 & 155.3 & 168.0 & 182.6 \\
\hline \multirow[t]{2}{*}{ December } & 118.9 & 136.9 & 154.2 & 167.6 & 182.3 \\
\hline & \multicolumn{5}{|c|}{ (Twelve-month percentage change) } \\
\hline January & 10.1 & 7.2 & 15.4 & 12.6 & 8.1 \\
\hline February & 9.0 & 7.2 & 15.6 & 12.9 & 7.0 \\
\hline March & 8.4 & 7.2 & 17.9 & 11.9 & 6.5 \\
\hline April & 7.8 & 7.4 & 17.8 & 11.9 & 6.4 \\
\hline May & 7.9 & 6.7 & 18.2 & 12.4 & 5.9 \\
\hline June & 6.7 & 9.1 & 16.7 & 12.6 & 5.4 \\
\hline July & 6.9 & 11.2 & 15.0 & 12.1 & 5.3 \\
\hline August & 8.1 & 12.6 & 14.9 & 9.2 & 6.6 \\
\hline September & 6.3 & 14.6 & 14.5 & 7.4 & 7.7 \\
\hline October & 7.1 & 14.3 & 14.5 & 6.8 & 9.4 \\
\hline November & 8.2 & 14.0 & 13.7 & 8.1 & 8.7 \\
\hline December & 7.5 & 15.2 & 12.6 & 8.7 & 8.8 \\
\hline Period average & 7.8 & 10.6 & 15.5 & 10.5 & 7.2 \\
\hline
\end{tabular}

Source: Data provided by the Lao P.D.R. authorities. 


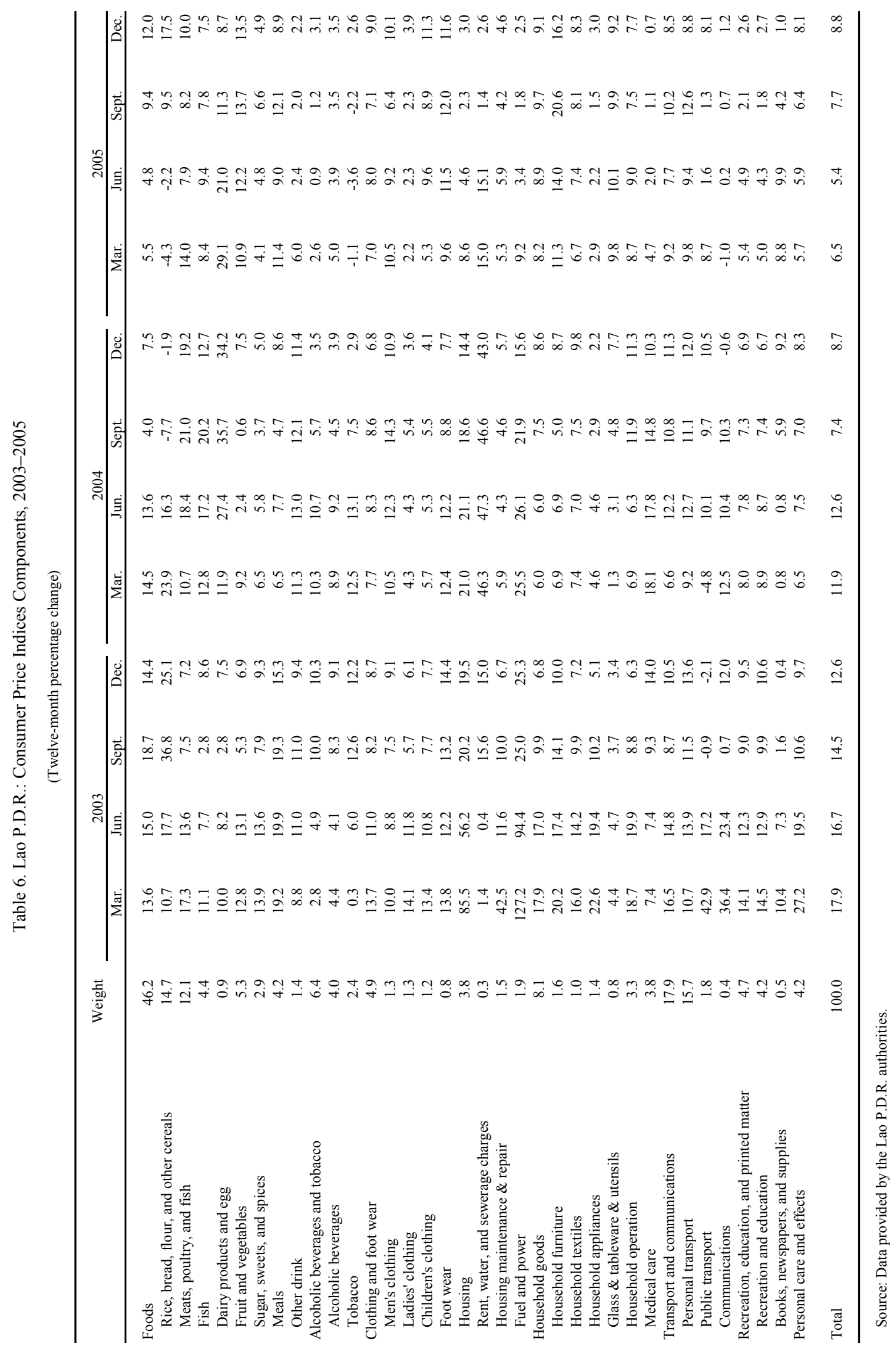


Table 7. Lao P.D.R.: General Government Operations, 2000/01-2004/05

\begin{tabular}{|c|c|c|c|c|c|}
\hline & $2000 / 01$ & $2001 / 02$ & $2002 / 03$ & $2003 / 04$ & $\begin{array}{r}2004 / 05 \\
\text { Authorities' est. }\end{array}$ \\
\hline & \multicolumn{5}{|c|}{ (In billions of kip) } \\
\hline Revenue and grants & 2,476 & 2,683 & 2,794 & 3,103 & 3,691 \\
\hline Revenue & 2,000 & 2,324 & 2,341 & 2,821 & 3,284 \\
\hline Tax & 1,629 & 1,875 & 1,924 & 2,328 & 2,700 \\
\hline Nontax & 372 & 449 & 417 & 493 & 584 \\
\hline Grants & 476 & 359 & 453 & 283 & 407 \\
\hline Expenditure & 3,141 & 3,268 & 4,017 & 3,967 & 4,958 \\
\hline Current & 1,123 & 1,280 & 1,527 & 1,890 & 2,350 \\
\hline Wage bill & 537 & 703 & 840 & 1,076 & 1,329 \\
\hline Wages, salaries and benefits & 410 & 547 & 668 & 833 & 1,077 \\
\hline Compensations and allowances & 127 & 156 & 172 & 243 & 252 \\
\hline Subsidies and transfers & 116 & 109 & 169 & 124 & 200 \\
\hline Interest payments & 134 & 138 & 123 & 235 & 290 \\
\hline of which: external & 117 & 108 & 115 & 194 & 267 \\
\hline Other recurrent & 336 & 330 & 394 & 456 & 530 \\
\hline Capital and onlending & 1,911 & 1,785 & 2,370 & 1,853 & 2,232 \\
\hline Domestically financed 1 / & 872 & 995 & 1,026 & 799 & 484 \\
\hline Externally financed & 1,200 & 931 & 1,499 & 1,169 & 1,878 \\
\hline Onlending (net) & -160 & -141 & -156 & -115 & -130 \\
\hline Debt repayment/Contingency & 107 & 203 & 120 & 224 & 377 \\
\hline Overall balance & -665 & -585 & $-1,222$ & -864 & $-1,267$ \\
\hline Financing & 665 & 585 & 1,222 & 864 & 1,267 \\
\hline Domestic financing (net) & 253 & -230 & 97 & -59 & 16 \\
\hline Bank financing 2/ & 246 & -234 & 92 & -66 & 2 \\
\hline Nonbank financing & 7 & 4 & 5 & 6 & 13 \\
\hline Foreign financing (net) 3/4/ & 545 & 409 & 1,108 & 923 & 1,254 \\
\hline Disbursements & 792 & 691 & 1,309 & 1,151 & 1,550 \\
\hline Amortization & -247 & -282 & -201 & -228 & -296 \\
\hline \multirow[t]{2}{*}{ Discrepancy/Financing gap } & $\ldots$ & $\ldots$ & 18 & 0 & -3 \\
\hline & \multicolumn{5}{|c|}{ (In percent of GDP) } \\
\hline Revenue and grants & 16.3 & 15.1 & 13.0 & 12.1 & 12.6 \\
\hline Revenue & 13.2 & 13.1 & 10.9 & 11.0 & 11.2 \\
\hline Tax & 10.7 & 10.6 & 8.9 & 9.1 & 9.2 \\
\hline Nontax & 2.4 & 2.5 & 1.9 & 1.9 & 2.0 \\
\hline Grants & 3.1 & 2.0 & 2.1 & 1.1 & 1.4 \\
\hline Expenditure & 20.7 & 18.4 & 18.6 & 15.5 & 16.9 \\
\hline Current & 7.4 & 7.2 & 7.1 & 7.4 & 8.0 \\
\hline Wage bill & 3.5 & 4.0 & 3.9 & 4.2 & 4.5 \\
\hline Wages, salaries and benefits & 2.7 & 3.1 & 3.1 & 3.3 & 3.7 \\
\hline Compensations and allowances & 0.8 & 0.9 & 0.8 & 1.0 & 0.9 \\
\hline Subsidies and transfers & 0.8 & 0.6 & 0.8 & 0.5 & 0.7 \\
\hline Interest payments & 0.9 & 0.8 & 0.6 & 0.9 & 1.0 \\
\hline of which: external & 0.8 & 0.6 & 0.5 & 0.8 & 0.9 \\
\hline Other recurrent & 2.2 & 1.9 & 1.8 & 1.8 & 1.8 \\
\hline Capital and onlending & 12.6 & 10.1 & 11.0 & 7.3 & 7.6 \\
\hline Domestically financed 1 / & 5.7 & 5.6 & 4.8 & 3.1 & 1.6 \\
\hline Externally financed & 7.9 & 5.3 & 7.0 & 4.6 & 6.4 \\
\hline Onlending (net) & -1.1 & -0.8 & -0.7 & -0.5 & -0.4 \\
\hline Debt repayment/Contingency & 0.7 & 1.1 & 0.6 & 0.9 & 1.3 \\
\hline Overall balance & -4.4 & -3.3 & -5.7 & -3.4 & -4.3 \\
\hline Financing & 4.4 & 3.3 & 5.7 & 3.4 & 4.3 \\
\hline Domestic financing (net) & 1.7 & -1.3 & 0.4 & -0.2 & 0.1 \\
\hline Foreign financing (net) $3 / 4$ / & 3.6 & 2.3 & 5.1 & 3.6 & 4.3 \\
\hline Discrepancy/Financing gap & 0.0 & 0.0 & 0.1 & 0.0 & 0.0 \\
\hline \multicolumn{6}{|l|}{ Memorandum items: } \\
\hline GDP (in billions of kip) & 15,194 & 17,726 & 21,549 & 25,555 & 29,313 \\
\hline Bank restructuring bonds 5 / & 0 & 0 & 139 & 108 & $\ldots$ \\
\hline Exchange rate (Kip per US dollar) & 8,586 & 9,810 & 10,636 & 10,594 & 10,604 \\
\hline
\end{tabular}

Sources: Data provided by the Lao P.D.R. authorities; and Fund staff estimates.

1/ In 2003/04 includes discrepancy.

$2 /$ Excludes bank restructuring bonds.

3/ In 2001/02 includes a transfer of \$33 million from EDL to the government from the Theun-Hinboun Power Company refinancing.

4/ Foreign financing does not include loans for government equity contribution to the NT2 project.

5/ In 2002/03 and 2003/04 the bonds were Debt Clearance Bonds issued to state banks to settle budget obligations to contractors with NPLs. In 2004/05 includes bank recapitalization bonds. 
Table 8. Lao P.D.R.: General Government Revenue, 2000/01-2004/05

\begin{tabular}{|c|c|c|c|c|c|}
\hline & $2000 / 01$ & $2001 / 02$ & $2002 / 03$ & $2003 / 04$ & $\frac{2004 / 05}{\text { Authorities' est. }}$ \\
\hline & \multicolumn{4}{|c|}{ (In billions of kip) } & \\
\hline Revenue & 2,000 & 2,324 & 2,341 & 2,821 & 3,284 \\
\hline Tax & 1,629 & 1,875 & 1,924 & 2,328 & 2,700 \\
\hline Profit tax & 205 & 239 & 221 & 222 & 252 \\
\hline Income tax & 145 & 125 & 140 & 179 & 217 \\
\hline Turnover tax & 318 & 375 & 466 & 594 & 656 \\
\hline Excise tax & 371 & 286 & 293 & 483 & 497 \\
\hline Import duties & 179 & 240 & 316 & 351 & 423 \\
\hline Timber royalty receipts & 182 & 362 & 218 & 225 & 190 \\
\hline Natural Resource Tax & 24 & 17 & 23 & 32 & 92 \\
\hline Hydro royalties & 51 & 46 & 45 & 32 & 57 \\
\hline Other Fees & 61 & 92 & 107 & 129 & 208 \\
\hline Other & 92 & 93 & 94 & 81 & 108 \\
\hline Nontax & 372 & 449 & 417 & 493 & 584 \\
\hline SOE dividends & 67 & 84 & 87 & 106 & 178 \\
\hline Overflight revenues & 114 & 187 & 174 & 202 & 222 \\
\hline \multirow[t]{2}{*}{ Other } & 190 & 177 & 156 & 185 & 185 \\
\hline & \multicolumn{4}{|c|}{ (In percent of GDP) } & \\
\hline Revenue & 13.2 & 13.1 & 10.9 & 11.0 & 11.2 \\
\hline Tax & 10.7 & 10.6 & 8.9 & 9.1 & 9.2 \\
\hline Profit tax & 1.4 & 1.4 & 1.0 & 0.9 & 0.9 \\
\hline Income tax & 1.0 & 0.7 & 0.6 & 0.7 & 0.7 \\
\hline Turnover tax & 2.1 & 2.1 & 2.2 & 2.3 & 2.2 \\
\hline Excise tax & 2.4 & 1.6 & 1.4 & 1.9 & 1.7 \\
\hline Import duties & 1.2 & 1.4 & 1.5 & 1.4 & 1.4 \\
\hline Timber royalty receipts & 1.2 & 2.0 & 1.0 & 0.9 & 0.6 \\
\hline Natural Resource Tax & 0.2 & 0.1 & 0.1 & 0.1 & 0.3 \\
\hline Hydro royalties & 0.3 & 0.3 & 0.2 & 0.1 & 0.2 \\
\hline Other & 0.6 & 0.5 & 0.4 & 0.3 & 0.4 \\
\hline Nontax & 2.4 & 2.5 & 1.9 & 1.9 & 2.0 \\
\hline SOE dividends & 0.4 & 0.5 & 0.4 & 0.4 & 0.6 \\
\hline Overflight revenues & 0.8 & 1.1 & 0.8 & 0.8 & 0.8 \\
\hline Other & 1.3 & 1.0 & 0.7 & 0.7 & 0.6 \\
\hline \multicolumn{6}{|l|}{ Memorandum item: } \\
\hline GDP (in billions of kip) & 15,194 & 17,726 & 21,549 & 25,555 & 29,313 \\
\hline
\end{tabular}

Sources: Data provided by the Lao P.D.R. authorities; and Fund staff estimates. 
Table 9. Lao P.D.R.: General Government Expenditures, 2000/01-2004/05

\begin{tabular}{|c|c|c|c|c|c|}
\hline & \multirow[t]{2}{*}{$2000 / 01$} & \multirow[t]{2}{*}{$2001 / 02$} & \multirow[t]{2}{*}{$2002 / 03$} & \multirow[t]{2}{*}{ 2003/04 } & \multirow{2}{*}{$\begin{array}{r}2004 / 05 \\
\text { Authorities' est }\end{array}$} \\
\hline & & & & & \\
\hline & \multicolumn{4}{|c|}{ (In billions of kip) } & \\
\hline Expenditure & 3,141 & 3,268 & 4,017 & 3,967 & 4,958 \\
\hline Current & 1,123 & 1,280 & 1,527 & 1,890 & 2,350 \\
\hline Wage bill & 537 & 703 & 840 & 1,076 & 1,329 \\
\hline Wages, salaries and benefits & 410 & 547 & 668 & 833 & 1,077 \\
\hline Salaries & 230 & 396 & 493 & 683 & $\ldots$ \\
\hline Remuneration & 180 & 152 & 175 & 150 & $\ldots$ \\
\hline Compensations and allowances & 127 & 156 & 172 & 243 & 252 \\
\hline of which: social welfare & 29 & 34 & 40 & 63 & $\ldots$ \\
\hline Subsidies and transfers & 116 & 109 & 169 & 124 & 200 \\
\hline Interest payments & 134 & 138 & 123 & 235 & 290 \\
\hline Domestic & 17 & 30 & 9 & 41 & 23 \\
\hline External & 117 & 108 & 115 & 194 & 267 \\
\hline Other recurrent & 336 & 330 & 394 & 456 & 530 \\
\hline Capital and onlending & 1,911 & 1,785 & 2,370 & 1,853 & 2,232 \\
\hline Domestically financed & 872 & 995 & 1,026 & 799 & 484 \\
\hline Externally financed & 1,200 & 931 & 1,499 & 1,169 & 1,878 \\
\hline Onlending (net) & -160 & -141 & -156 & -115 & -130 \\
\hline \multirow[t]{2}{*}{ Debt repayment } & 107 & 203 & 120 & 224 & 377 \\
\hline & \multicolumn{4}{|c|}{ (In percent of GDP) } & \\
\hline Expenditure & 20.7 & 18.4 & 18.6 & 15.5 & 16.9 \\
\hline Current & 7.4 & 7.2 & 7.1 & 7.4 & 8.0 \\
\hline Wage bill & 3.5 & 4.0 & 3.9 & 4.2 & 4.5 \\
\hline Wages, salaries and benefits & 2.7 & 3.1 & 3.1 & 3.3 & 3.7 \\
\hline Salaries & 1.5 & 2.2 & 2.3 & 2.7 & $\ldots$ \\
\hline Remuneration & 1.2 & 0.9 & 0.8 & 0.6 & $\ldots$ \\
\hline Compensations and allowances & 0.8 & 0.9 & 0.8 & 1.0 & 0.9 \\
\hline of which: social welfare & 0.2 & 0.2 & 0.2 & 0.2 & $\ldots$ \\
\hline Subsidies and transfers & 0.8 & 0.6 & 0.8 & 0.5 & 0.7 \\
\hline Interest payments & 0.9 & 0.8 & 0.6 & 0.9 & 1.0 \\
\hline Domestic & 0.1 & 0.2 & 0.0 & 0.2 & 0.1 \\
\hline External & 0.8 & 0.6 & 0.5 & 0.8 & 0.9 \\
\hline Other recurrent & 2.2 & 1.9 & 1.8 & 1.8 & 1.8 \\
\hline Capital and onlending & 12.6 & 10.1 & 11.0 & 7.3 & 7.6 \\
\hline Domestically financed & 5.7 & 5.6 & 4.8 & 3.1 & 1.6 \\
\hline Externally financed & 7.9 & 5.3 & 7.0 & 4.6 & 6.4 \\
\hline Onlending (net) & -1.1 & -0.8 & -0.7 & -0.5 & -0.4 \\
\hline Debt repayment & 0.7 & 1.1 & 0.6 & 0.9 & 1.3 \\
\hline \multicolumn{6}{|l|}{ Memorandum item: } \\
\hline GDP (in billions of kip) & 15,194 & 17,726 & 21,549 & 25,555 & 29,313 \\
\hline
\end{tabular}

Sources: Data provided by the Lao P.D.R. authorities; and Fund staff estimates. 


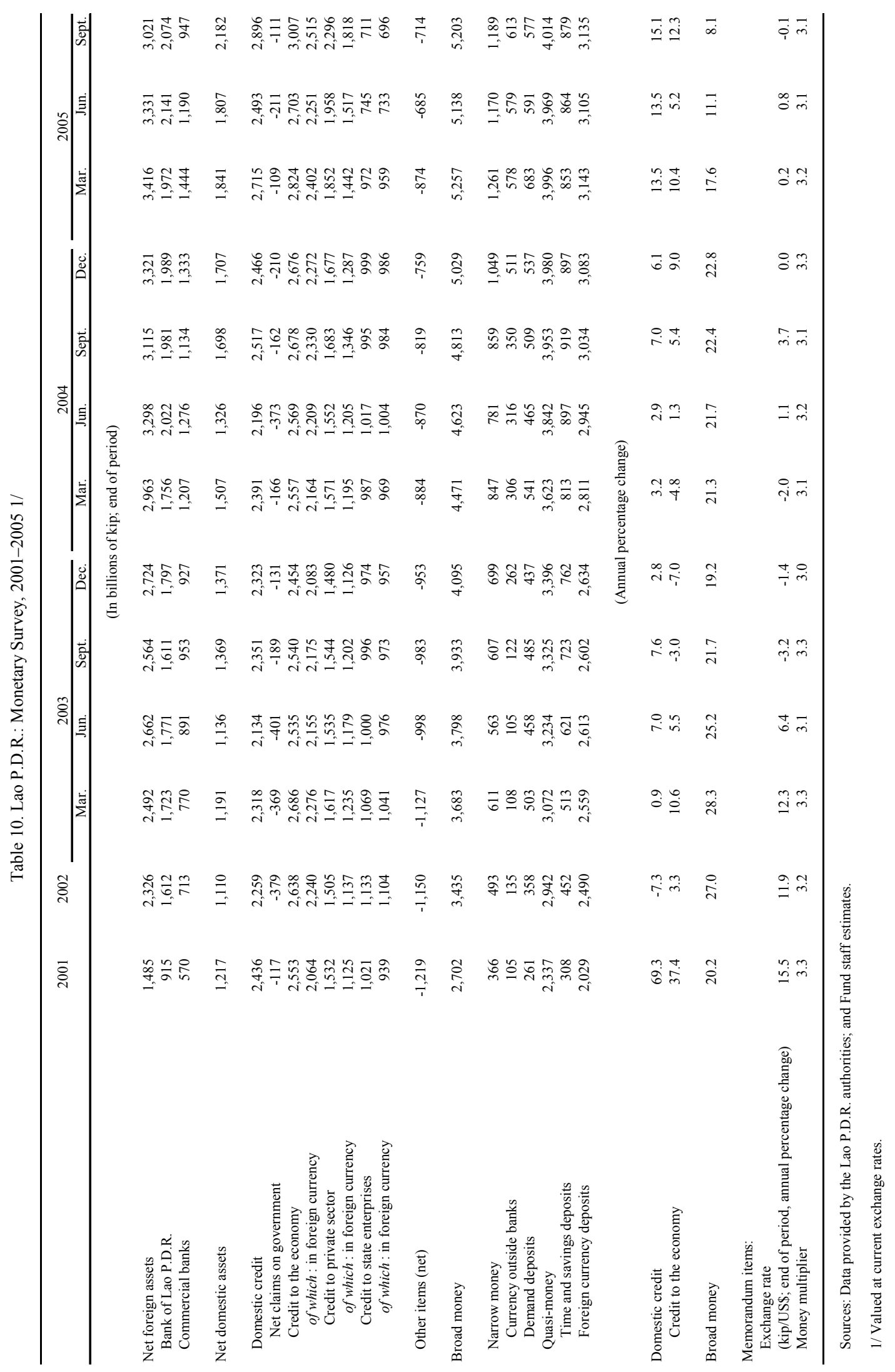




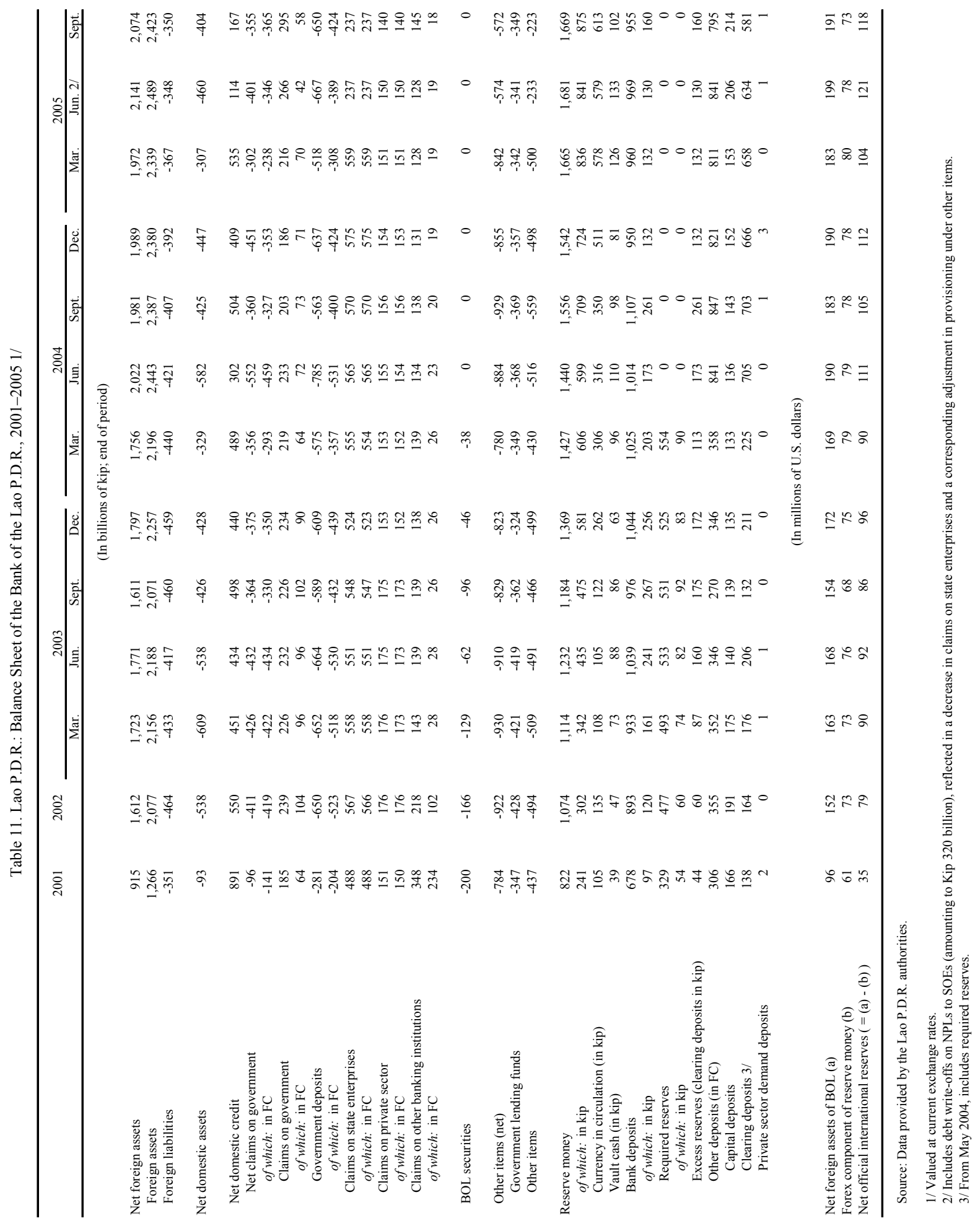




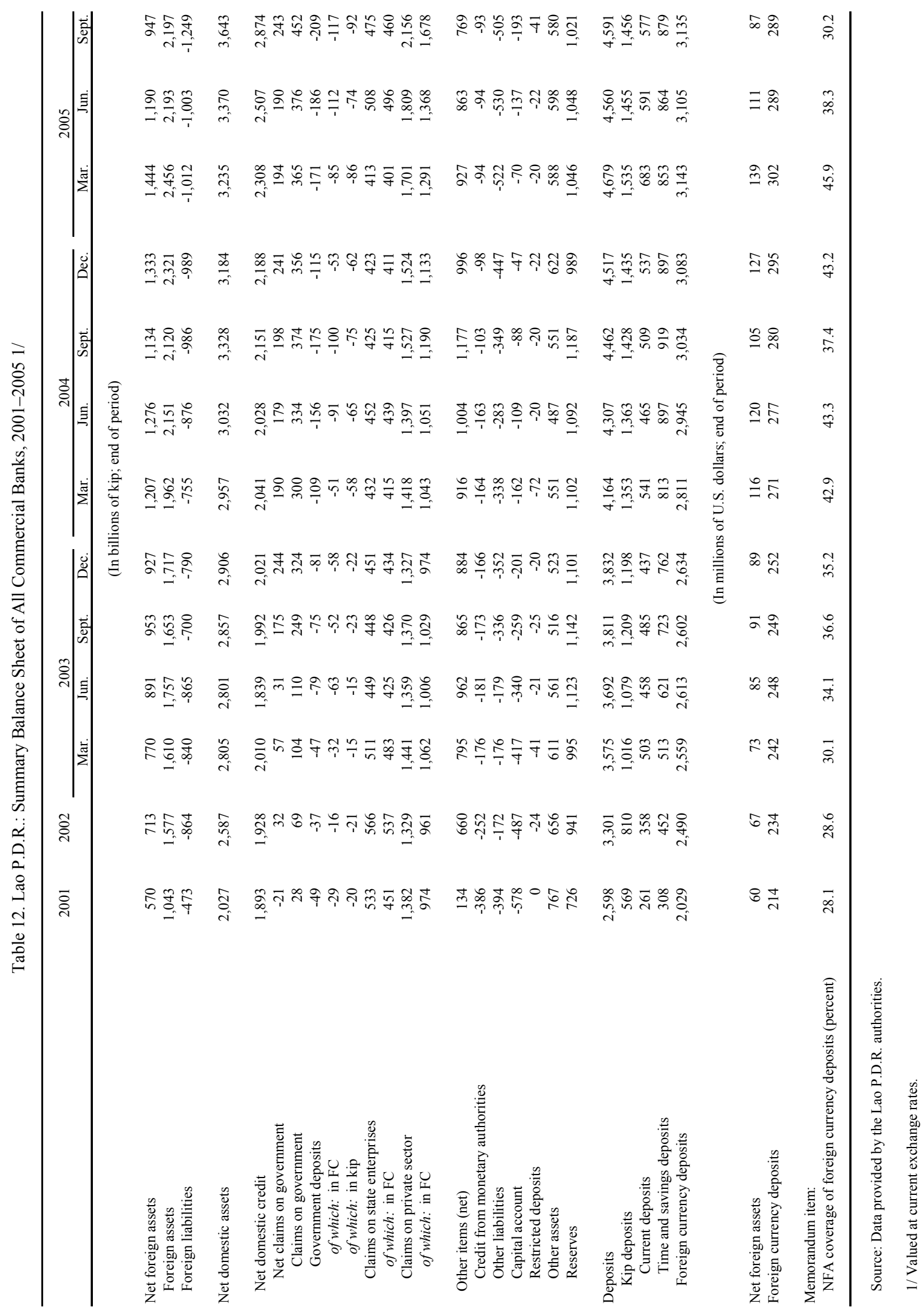




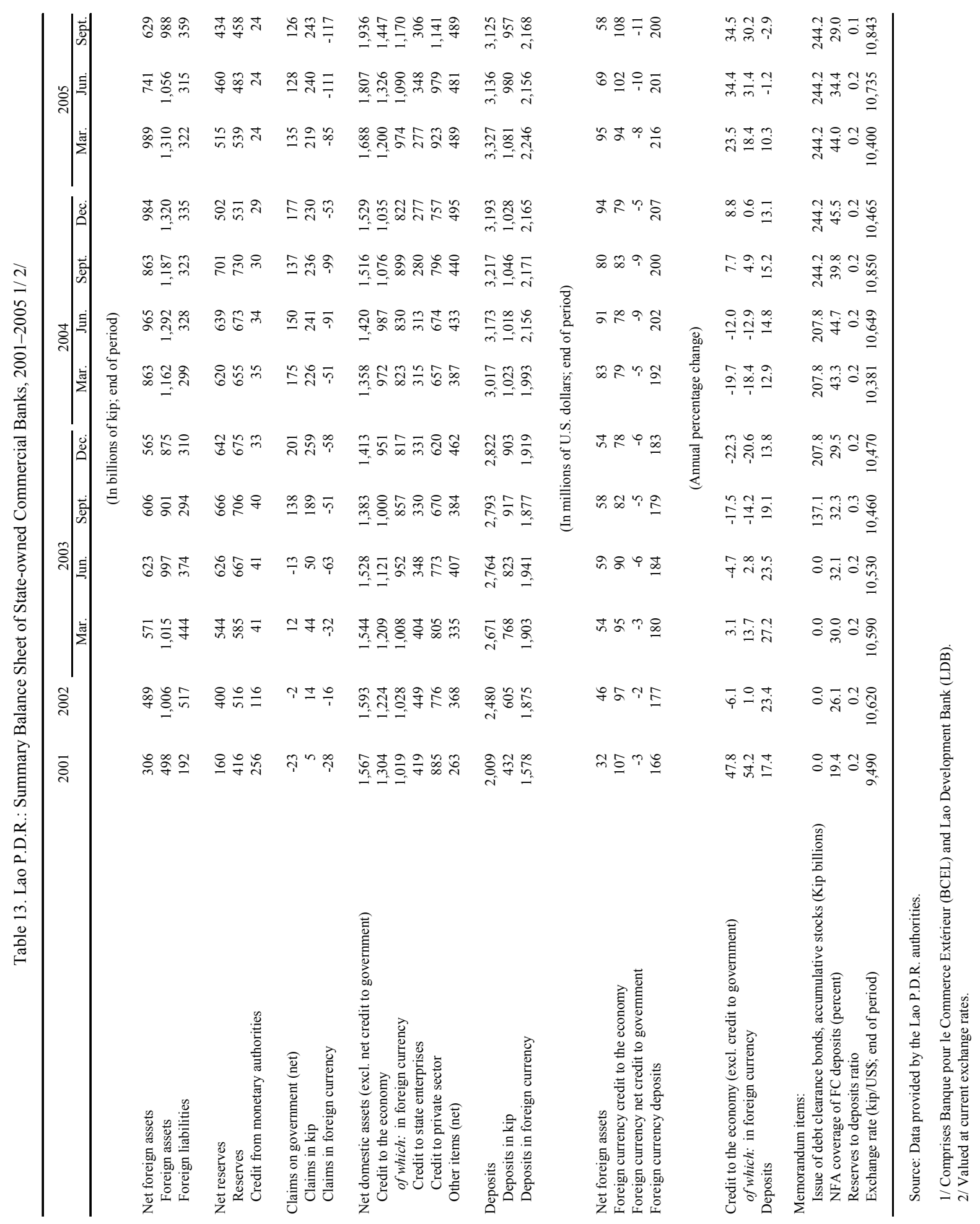


Table 14. Lao P.D.R.: Interest Rates, 2000-2005

\begin{tabular}{|c|c|c|c|c|c|c|c|}
\hline & \multirow[t]{2}{*}{2000} & \multirow[t]{2}{*}{2001} & \multirow[t]{2}{*}{2002} & \multirow[t]{2}{*}{2003} & \multirow[t]{2}{*}{2004} & \multicolumn{2}{|c|}{2005} \\
\hline & & & & & & \multirow[t]{2}{*}{ Jun. } & \multirow[t]{2}{*}{ Sept. } \\
\hline & \multicolumn{5}{|c|}{ (In percent; end of period) } & & \\
\hline \multicolumn{8}{|c|}{ Local banks (representative rates) $1 /$} \\
\hline \multicolumn{8}{|l|}{ Deposit rates } \\
\hline Savings (U.S. dollar accounts) & 3.0 & 2.0 & 1.0 & 0.4 & 0.3 & 0.4 & 0.5 \\
\hline \multicolumn{8}{|l|}{ Fixed (U.S. dollar accounts) } \\
\hline 3 months & 4.0 & 2.5 & 1.5 & 0.5 & 0.4 & 0.5 & 0.8 \\
\hline 6 months & 5.0 & 3.0 & 1.8 & 0.6 & 0.8 & 0.8 & 1.0 \\
\hline 12 months & 6.0 & 3.5 & 2.3 & 0.8 & 1.0 & 1.0 & 1.0 \\
\hline Savings (Kip accounts) & 12.0 & 12.0 & 15.0 & 12.0 & 5.0 & 3.0 & 3.0 \\
\hline \multicolumn{8}{|l|}{ Fixed (Kip accounts) } \\
\hline 3 months & 15.0 & 16.0 & 17.0 & 15.0 & 8.0 & 5.0 & 5.0 \\
\hline 6 months & 20.0 & 18.0 & 19.0 & 18.0 & 9.0 & 7.0 & 7.0 \\
\hline 12 months & 24.0 & 20.0 & 21.0 & 20.0 & 10.0 & 8.0 & 8.0 \\
\hline \multicolumn{8}{|l|}{ Lending rates } \\
\hline \multicolumn{8}{|l|}{ Overdraft } \\
\hline Kip & 30.0 & 24.0 & 24.0 & 28.0 & 21.0 & 20.0 & 20.0 \\
\hline Baht & 12.0 & 10.0 & 10.0 & 12.0 & 12.0 & 12.0 & 12.0 \\
\hline U.S. dollar & 11.0 & 11.0 & 11.0 & 11.0 & 12.0 & 12.0 & 12.0 \\
\hline \multicolumn{8}{|c|}{ Foreign banks (representative rates) 2/ } \\
\hline \multicolumn{8}{|l|}{ Deposit rates } \\
\hline Savings (U.S. dollar accounts) & 1.0 & 0.5 & 0.5 & 0.5 & 0.3 & 0.3 & 0.3 \\
\hline \multicolumn{8}{|l|}{ Fixed (U.S. dollar accounts) } \\
\hline 3 months & 1.0 & 1.0 & 1.0 & 1.0 & 0.5 & 0.5 & 0.5 \\
\hline 6 months & 1.5 & 1.0 & 1.0 & 1.0 & 0.5 & 0.5 & 0.5 \\
\hline 12 months & 3.0 & 2.0 & 2.0 & 2.0 & 0.8 & 0.8 & 0.8 \\
\hline \multicolumn{8}{|l|}{ Lending rates } \\
\hline \multicolumn{8}{|l|}{ Overdraft } \\
\hline Kip & 23.0 & 22.0 & 22.0 & 22.0 & 22.0 & 22.0 & 22.0 \\
\hline Baht & 17.0 & 14.0 & 14.0 & 14.0 & 13.0 & 13.0 & 13.0 \\
\hline U.S. dollar & 13.0 & 11.0 & 11.0 & 11.0 & 10.5 & 10.5 & 10.5 \\
\hline
\end{tabular}

Source: Data provided by the Lao P.D.R. authorities.

1/ Local banks representative rates are from BCEL.

2 / Foreign banks representative rates are from THMB. 
Table 15. Lao P.D.R.: Balance of Payments, 2000-2004

(In millions of U.S. dollars; unless otherwise indicated)

\begin{tabular}{|c|c|c|c|c|c|}
\hline & 2000 & 2001 & 2002 & 2003 & $\frac{2004}{\text { Est }}$ \\
\hline Current account & -183 & -146 & -131 & -174 & -361 \\
\hline Excluding official transfers & -299 & -209 & -180 & -237 & -420 \\
\hline Merchandise trade balance & -376 & -288 & -263 & -244 & -478 \\
\hline Exports, f.o.b. & 342 & 362 & 370 & 450 & 500 \\
\hline Imports, c.i.f. & 718 & 650 & 633 & 694 & 977 \\
\hline Services (net) & 132 & 125 & 131 & 95 & 132 \\
\hline Income (net) & -75 & -67 & -70 & -113 & -101 \\
\hline of which: interest payments $1 /$ & -38 & -35 & -29 & -38 & -54 \\
\hline of which: public debt & -11 & -11 & -10 & -15 & -27 \\
\hline Transfers (net) & 136 & 85 & 71 & 87 & 85 \\
\hline Private & 21 & 22 & 23 & 24 & 26 \\
\hline Official & 115 & 63 & 48 & 63 & 60 \\
\hline Capital account & 227 & 145 & 187 & 196 & 379 \\
\hline Medium- and Long-Term Loans & 63 & 66 & 127 & 120 & 275 \\
\hline Disbursements 2/ & 99 & 105 & 165 & 176 & 346 \\
\hline Amortization & -36 & -39 & -38 & -56 & -70 \\
\hline of which: public debt & -20 & -25 & -27 & -28 & -29 \\
\hline Foreign direct investment & 31 & 24 & 60 & 39 & 98 \\
\hline Net foreign assets of commercial banks (increase -) & 25 & 28 & -7 & -21 & -39 \\
\hline Other private flows and errors and omissions & 108 & 27 & 6 & 58 & 45 \\
\hline Overall balance & 44 & -1 & 55 & 22 & 18 \\
\hline Financing & -44 & 1 & -55 & -22 & -18 \\
\hline Central bank net foreign assets & -44 & 1 & -55 & -22 & -18 \\
\hline Assets (increase -) & -33 & 6 & -62 & -18 & -12 \\
\hline Liabilities (reduction -) & -10 & -5 & 7 & -4 & -6 \\
\hline \multicolumn{6}{|l|}{ Memorandum items: } \\
\hline \multicolumn{5}{|l|}{ Current account (percent of GDP) } & -16.8 \\
\hline \multicolumn{6}{|l|}{ Gross official reserves } \\
\hline (in millions of U.S. dollars) & 127 & 134 & 196 & 214 & 227 \\
\hline (in months of goods and services imports) & 2.2 & 2.4 & 3.0 & 3.7 & 3.4 \\
\hline \multicolumn{6}{|l|}{ Public debt service ratio } \\
\hline (in percent of exports of goods and services) & 5.8 & 7.2 & 7.1 & 6.7 & 7.5 \\
\hline Nominal GDP at market prices (US\$ million) & 1,740 & 1,762 & 1,818 & 2,138 & 2,501 \\
\hline
\end{tabular}

Sources: Data provided by the Lao P.D.R. authorities; and Fund staff estimates.

1/ Includes debt service to official creditors and estimates for debt service to commercial creditors. 2/ Includes private sector loans. 


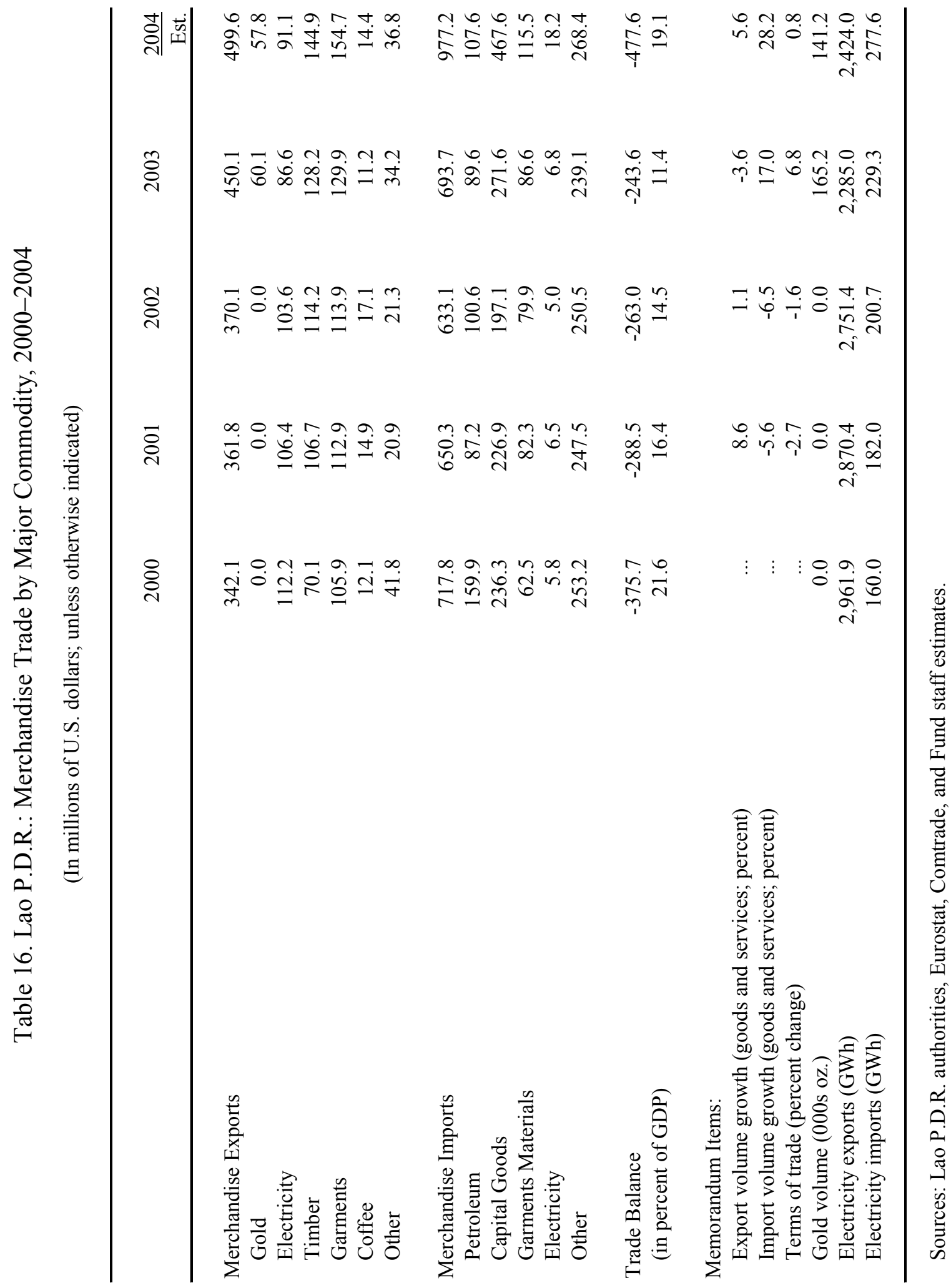


Table 17. Lao P.D.R.: External Aid and Loan Disbursements, 2000-2004 (In millions of U.S. dollars)

\begin{tabular}{|c|c|c|c|c|c|}
\hline & 2000 & 2001 & 2002 & 2003 & 2004 \\
\hline Grants 1/ & 115.0 & 63.2 & 47.7 & 63.0 & 59.5 \\
\hline Bilateral & 114.6 & 63.0 & 43.0 & 61.0 & 56.4 \\
\hline Program grants & 0.0 & 2.8 & 12.0 & 12.3 & 12.6 \\
\hline Project grants & 114.6 & 60.2 & 31.0 & 48.7 & 43.8 \\
\hline Of which: Technical assistance & 22.1 & 11.2 & 7.7 & 6.0 & $\ldots$ \\
\hline Multilateral & 0.4 & 0.2 & 4.7 & 2.0 & 3.2 \\
\hline UN agencies & 0.1 & 0.0 & 3.6 & 1.8 & 0.1 \\
\hline AsDB & 0.0 & 0.0 & 0.2 & 0.1 & 0.4 \\
\hline Other (including NGOs) & 0.3 & 0.2 & 0.8 & 0.1 & 2.6 \\
\hline Loan disbursements & 98.3 & 105.1 & 105.0 & 128.9 & 113.8 \\
\hline Program loans & 11.3 & 0.0 & 5.0 & 22.0 & 12.3 \\
\hline IDA & 0.0 & 0.0 & 0.0 & 7.0 & 12.3 \\
\hline AsDB & 11.3 & 0.0 & 5.0 & 15.0 & 0.0 \\
\hline Project loans & 87.0 & 105.1 & 100.0 & 106.9 & 101.5 \\
\hline AsDB & 37.7 & 51.9 & 36.0 & 46.0 & 51.8 \\
\hline IDA & 26.8 & 36.4 & 47.8 & 39.6 & 27.5 \\
\hline IFAD & 2.5 & 4.2 & 5.5 & 3.0 & 3.8 \\
\hline OPEC & 4.6 & 3.9 & 1.8 & 2.0 & 2.6 \\
\hline Nordic Fund & 2.5 & 6.8 & 1.1 & 1.4 & 6.0 \\
\hline OECF & 0.0 & 0.4 & 2.2 & 0.0 & 0.0 \\
\hline Other & 12.9 & 1.5 & 5.6 & 14.9 & 9.7 \\
\hline
\end{tabular}

Sources: Data provided by the Lao P.D.R. authorities; and Fund staff estimates.

1/ Includes project related and general technical assistance. 
Table 18. Lao P.D.R.: International Reserves, 2000-2004

(In millions of U.S. dollars)

\begin{tabular}{lrrrrr}
\hline & 2000 & 2001 & 2002 & 2003 & 2004 \\
\hline Net foreign assets of the banking system & 185.9 & 150.3 & 219.0 & 260.2 & 317.4 \\
$\quad$ Foreign assets & 270.6 & 253.5 & 344.1 & 379.5 & 449.3 \\
$\quad$ Foreign liabilities & 84.7 & 103.2 & 125.1 & 119.4 & 131.9 \\
& & & & & \\
Central bank net foreign assets & 97.2 & 95.6 & 151.8 & 171.7 & 190.0 \\
$\quad$ Foreign assets & 139.6 & 133.5 & 195.6 & 215.5 & 227.5 \\
$\quad$ Foreign liabilities & 42.3 & 37.9 & 43.7 & 43.9 & 37.4 \\
$\quad$ & 88.7 & 54.7 & 67.2 & 88.5 & 127.4 \\
Commercial banks' net foreign assets & 131.1 & 120.0 & 148.5 & 164.0 & 221.8 \\
$\quad$ Foreign assets & 42.3 & 65.3 & 81.3 & 75.5 & 94.5 \\
$\quad$ Foreign liabilities & & & & & \\
\end{tabular}

Source: Data provided by the Lao P.D.R. authorities. 
Table 19. Lao P.D.R.: Debt Stock and Debt Service, 2000-2004 1/ (In millions of U.S. dollars)

\begin{tabular}{|c|c|c|c|c|c|}
\hline & 2000 & 2001 & 2002 & 2003 & $\frac{2004}{\text { Est. }}$ \\
\hline Total debt stock (public and private) & 1,447 & 1,458 & 1,614 & 2,171 & 2,530 \\
\hline Public debt & 1,179 & 1,213 & 1,330 & 1,915 & 2,086 \\
\hline $\begin{array}{l}\text { Bilateral official } \\
\text { of which: Russian Federation }\end{array}$ & $\begin{array}{c}79 \\
\ldots\end{array}$ & $\begin{array}{c}68 \\
\ldots\end{array}$ & $\begin{array}{c}64 \\
\ldots\end{array}$ & $\begin{array}{l}437 \\
387\end{array}$ & $\begin{array}{l}453 \\
387\end{array}$ \\
\hline $\begin{array}{l}\text { Multilateral } \\
\text { of which: }\end{array}$ & 1,042 & 1,089 & 1,191 & 1,338 & 1,516 \\
\hline AsDB & 541 & 575 & 603 & 715 & 754 \\
\hline IDA & 394 & 407 & 435 & 485 & 618 \\
\hline IMF & 48 & 37 & 43 & 46 & 38 \\
\hline Commercial & 58 & 56 & 75 & 140 & 117 \\
\hline Private debt & 268 & 245 & 284 & 257 & 444 \\
\hline Total debt service & 81 & 84 & 76 & 91 & 120 \\
\hline Amortization & 43 & 49 & 47 & 56 & 70 \\
\hline Public debt & 20 & 25 & 27 & 28 & 29 \\
\hline Bilateral official & 2 & 4 & 4 & 1 & 5 \\
\hline Multilateral & 17 & 20 & 23 & 26 & 22 \\
\hline of which: IMF & 8 & 9 & 9 & 9 & 3 \\
\hline Commercial & 0 & 1 & 0 & 0 & 4 \\
\hline Private debt & 24 & 24 & 20 & 27 & 41 \\
\hline Interest payments & 38 & 35 & 29 & 35 & 49 \\
\hline Public debt & 11 & 11 & 10 & 12 & 22 \\
\hline Bilateral (official debt) & 1 & 1 & 1 & 1 & 5 \\
\hline Multilateral & 9 & 9 & 9 & 11 & 16 \\
\hline of which: IMF & 1 & 1 & 0 & 0 & 0 \\
\hline Commercial & 1 & 1 & 0 & 0 & 2 \\
\hline Private debt & 27 & 24 & 20 & 23 & 27 \\
\hline
\end{tabular}

Sources: Data provided by the Lao P.D.R. authorities; and Fund staff estimates.

$1 /$ Debt service and the stock of debt are calculated on the basis of existing debt, and currently identified disbursements. 
Table 20. Lao P.D.R.: Composition of Net Foreign Income, 2000-2004

(In millions of U.S. dollars; unless otherwise indicated)

\begin{tabular}{|c|c|c|c|c|c|}
\hline & 2000 & 2001 & 2002 & 2003 & 2004 \\
\hline Receipts & 7.3 & 5.6 & 4.7 & 3.5 & 12.5 \\
\hline Payments to Lao workers by embassies & 0.6 & 0.6 & 0.7 & 0.7 & 0.8 \\
\hline Interest on Bank of Lao P.D.R. reserve assets & 4.2 & 3.9 & 1.9 & 1.9 & 4.2 \\
\hline Interest on commercial banks nostro accounts & 2.5 & 1.1 & 2.1 & 0.9 & 7.5 \\
\hline Income from royalty & 0.0 & 0.0 & 0.0 & 0.0 & 0.0 \\
\hline Payments & 78.0 & 74.0 & 69.0 & 116.3 & 113.2 \\
\hline Payments to foreign workers in Lao embassies & 0.4 & 0.4 & 0.4 & 0.5 & 0.5 \\
\hline Income from direct investment in Lao P.D.R. & 34.6 & 36.7 & 36.2 & 77.7 & 58.9 \\
\hline Interest on official borrowing & 10.0 & 10.2 & 9.5 & 11.9 & 22.4 \\
\hline Interest on Bank of Lao P.D.R. foreign liabilities & 0.6 & 0.6 & 0.7 & 0.0 & 0.1 \\
\hline Interest on commercial banks foreign liabilities & 5.5 & 2.0 & 2.6 & 3.2 & 4.5 \\
\hline Interest payable on other private debt & 26.9 & 24.1 & 19.5 & 23.1 & 26.8 \\
\hline Net foreign income & -70.6 & -68.4 & -64.3 & -112.8 & -100.7 \\
\hline (in percent of GDP) & -4.1 & -3.9 & -3.5 & -5.3 & -4.0 \\
\hline
\end{tabular}

Sources: Data provided by the Lao P.D.R. authorities; and Fund staff estimates. 
Table 21. Lao P.D.R.: Composition of Net Services, 2000-2004

(In millions of U.S. dollars; unless otherwise indicated)

\begin{tabular}{|c|c|c|c|c|c|}
\hline & 2000 & 2001 & 2002 & 2003 & 2004 \\
\hline Receipts & 175.6 & 166.0 & 176.3 & 147.5 & 187.0 \\
\hline Transportation & 19.7 & 22.7 & 29.8 & 21.0 & 29.7 \\
\hline Overflight & 11.3 & 14.9 & 22.1 & 18.0 & 21.9 \\
\hline Freight to Lao carriers (exports) & 2.9 & 2.7 & 2.6 & 2.6 & 2.8 \\
\hline International fares to Lao carriers & 3.7 & 3.5 & 3.4 & 3.2 & 3.2 \\
\hline Lao port charges & 1.8 & 1.6 & 1.8 & 1.6 & 1.8 \\
\hline Travel & 113.9 & 103.8 & 106.8 & 84.0 & 119.0 \\
\hline Communications & 15.7 & 13.7 & 14.7 & 15.6 & 16.5 \\
\hline Insurance & 0.8 & 0.3 & 1.0 & 2.2 & 2.6 \\
\hline Embassies (nonsalary) & 25.5 & 25.5 & 24.0 & 24.7 & 19.2 \\
\hline Payments & 43.1 & 43.8 & 44.3 & 52.1 & 55.1 \\
\hline Transportation & 4.9 & 5.4 & 5.7 & 6.0 & 6.5 \\
\hline International fares to foreign carriers & 4.1 & 4.3 & 4.5 & 4.7 & 5.2 \\
\hline Foreign port charges & 0.8 & 1.1 & 1.2 & 1.2 & 1.3 \\
\hline Travel & 8.1 & 8.4 & 13.5 & 13.5 & 14.7 \\
\hline Communications & 4.3 & 5.6 & 4.4 & 4.4 & 5.0 \\
\hline Construction & 11.9 & 15.6 & 14.3 & 16.5 & 16.8 \\
\hline Hydropower & 0.5 & 0.0 & 0.0 & 0.0 & 0.0 \\
\hline Other projects & 11.4 & 15.6 & 14.3 & 16.5 & 16.8 \\
\hline Technical assistance ( 50 percent of inflow) & 11.5 & 5.6 & 2.2 & 4.2 & 4.9 \\
\hline Lao embassies abroad (nonsalary) & 2.4 & 2.4 & 2.4 & 3.2 & 2.4 \\
\hline Services (net) & 132.5 & 122.2 & 132.0 & 95.4 & 131.9 \\
\hline (in percent of GDP) & 7.6 & 6.9 & 7.3 & 4.5 & 5.3 \\
\hline \multicolumn{6}{|l|}{ Memorandum item: } \\
\hline Tourist arrivals (000s) & 737.2 & 673.8 & 735.7 & 636.4 & 894.8 \\
\hline
\end{tabular}

Sources: Data provided by the Lao P.D.R. authorities; and Fund staff estimates. 
Table 22. Lao P.D.R.: Domestic and Foreign Investment by Sector, 1999-2003 (In millions of U.S. dollars)

\begin{tabular}{lrrrrr}
\hline & 1999 & 2000 & 2001 & 2002 & 2003 \\
\hline Power & 151 & 0 & 360 & 22 & 73 \\
Telecommunication & 1 & 0 & 0 & 13 & 0 \\
Hotel-Restaurant & 0 & 0 & 1 & 24 & 34 \\
Industries-Handicrafts & 46 & 11 & 5 & 64 & 23 \\
Service & 8 & 10 & 12 & 13 & 127 \\
Wood Industries & 0 & 2 & 2 & 5 & 3 \\
Agriculture & 66 & 8 & 13 & 6 & 7 \\
Construction & 1 & 0 & 1 & 14 & 36 \\
Mining & 5 & 2 & 9 & 2 & 22 \\
Trading & 6 & 1 & 6 & 10 & 11 \\
Bank & 10 & 0 & 0 & 0 & 0 \\
Garment & 1 & 4 & 0 & 5 & 1 \\
Consultance & 0 & 0 & 1 & 1 & 1 \\
Grand Total & & & & & 337 \\
& 296 & 38 & 408 & 180 & \\
\hline
\end{tabular}

Source: Data provided by the Lao P.D.R. authorities. 
Table 23. Lao P.D.R.: Domestic and Foreign Investment by Country, 1999-2003 (In millions of U.S. dollars)

\begin{tabular}{|c|c|c|c|c|c|}
\hline & 1999 & 2000 & 2001 & 2002 & 2003 \\
\hline Thailand & 7 & 3 & 4 & 14 & 81 \\
\hline Lao P.D.R. & 38 & 0 & 90 & 22 & 11 \\
\hline USA & 115 & 0 & 3 & 8 & 2 \\
\hline Malaysia & 15 & 4 & 0 & 27 & 30 \\
\hline France & 1 & 3 & 11 & 9 & 16 \\
\hline China & 43 & 11 & 12 & 55 & 115 \\
\hline Vietnam & 15 & 2 & 273 & 6 & 6 \\
\hline Korea & 4 & 9 & 9 & 15 & 5 \\
\hline Norway & 0 & 0 & 0 & 0 & 22 \\
\hline Taiwan & 1 & 0 & 0 & 3 & 0 \\
\hline Singapore & 2 & 0 & 0 & 1 & 36 \\
\hline New Zealand & 51 & 0 & 0 & 0 & 0 \\
\hline Australia & 0 & 0 & 0 & 2 & 5 \\
\hline Russia & 0 & 0 & 0 & 1 & 2 \\
\hline United kingdom & 4 & 0 & 0 & 1 & 5 \\
\hline Japan & 2 & 3 & 0 & 1 & 1 \\
\hline Canada & 0 & 0 & 0 & 1 & 0 \\
\hline Sweden & 0 & 0 & 0 & 13 & 0 \\
\hline Germany & 0 & 0 & 1 & 0 & 0 \\
\hline Switzerland & 0 & 2 & 1 & 0 & 0 \\
\hline Belgium & 0 & 0 & 0 & 0 & 0 \\
\hline Cambodia & 0 & 1 & 1 & 0 & 0 \\
\hline India & 0 & 1 & 0 & 0 & 0 \\
\hline Finland & 0 & 0 & 0 & 1 & 0 \\
\hline Island & 0 & 0 & 0 & 1 & 0 \\
\hline Italy & 1 & 0 & 0 & 0 & 0 \\
\hline Netherlands & 0 & 0 & 0 & 0 & 0 \\
\hline Denmark & 0 & 0 & 0 & 0 & 0 \\
\hline Indonesia & 0 & 0 & 0 & 0 & 0 \\
\hline Austria & 0 & 0 & 0 & 0 & 0 \\
\hline Myanmar & 0 & 0 & 0 & 0 & 0 \\
\hline Luxembourg & 0 & 0 & 0 & 0 & 0 \\
\hline Ukraine & 0 & 0 & 0 & 0 & 0 \\
\hline Cuba & 0 & 0 & 0 & 0 & 0 \\
\hline Bangladesh & 0 & 0 & 0 & 0 & 0 \\
\hline Other & 0 & 0 & 0 & 0 & 0 \\
\hline Total & 296 & 38 & 408 & 180 & 337 \\
\hline
\end{tabular}

Source: Data provided by the Lao P.D.R. authorities. 